\title{
Palaeoproterozoic dome-forming structures related to granulite-facies metamorphism, Jequié block, Bahia, Brazil: petrogenetic approaches
}

\author{
Johildo Barbosa $^{\mathrm{a}, *}$, Hervé Martin $^{\mathrm{b}}$, Jean-Jacques Peucat ${ }^{\mathrm{c}}$ \\ a CPGG-Centro de Pesquisa em Geofisica e Geologia, UFBA-Universidade Federal da Bahia, Rua Caetano Moura 123, \\ Federação, 40210-340 Salvador, Bahia, Brazil \\ b Laboratoire Magmas et Volcans, Département de Géologie, OPGC-CNRS_Université Blaise Pascal, 5, Rue Kessler, \\ 63038 Clermont-Ferrand, France \\ c Géosciences Rennes, UMR CNRS, 35042 Rennes Cedex, France
}

Received 15 July 2003; accepted 4 August 2004

\begin{abstract}
Dome structures in the São Francisco craton (Northeast Brazil), have been identified in the regions of Brejões and Santa Inês within the granulitic Jequié block. Domes are mainly composed of $\mathrm{CH} 6$ charnockites, which intrude various granulites of the basement. The Brejões dome is surrounded by a rim of supracrustal rocks. The enderbite-charnockite suites $\mathrm{CH} 1$ and $\mathrm{CH} 2$, which are partially included in the basement and were previously dated ca $2.8-2.7 \mathrm{Ga}$, are similar to modern calc-alkaline suites and could be derived by partial melting of an enriched tholeiite (degree of fractionation ca 24-23\%). An older Archaean component is suggested by negative $\varepsilon_{\mathrm{Nd}}$ values at $2.8-2.7 \mathrm{Ga}$ which range between -1 and -4 and $\mathrm{Nd}$ model ages with an average ca $3.1 \mathrm{Ga}$. These magmatic suites are ascribed to the amphibolite-facies based on preserved prograde mineral assemblages and results of geochemical modelling. The $\mathrm{CH} 6$ rocks formed in domes are of granitic composition. They mainly derive from partial melting of the $2.7 \mathrm{Ga} \mathrm{CH} 2$ basement suite. The hercynite-quartz assemblage in supracrustal rocks surrounding the Brejões dome suggests very high temperature $\left(>1000^{\circ} \mathrm{C}\right)$ for the $\mathrm{CH} 6$ magmas which would have induced partial melting in adjacent supracrustal rocks, forming garnet-cordierite-bearing granitic melts. Emplacement of domes is constrained by the age of the granulite facies metamorphism in the Jequié block (ca $2.1 \mathrm{Ga}$ ) and the average cooling age of monazite which occurred in the syn-dome charnockite and the surrounding heterogeneous granulites of the basement at $2045 \pm 2.5 \mathrm{Ma}$. A southern dome exhibits a younger monazite age of $2026 \pm 1 \mathrm{Ma}$, which may suggest a broader age span for the doming event.
\end{abstract}

(c) 2004 Elsevier B.V. All rights reserved.

Keywords: Archaean enderbite-charnockite suites; Palaeoproterozoic charnockite domes; Geochemical modelling; Geochronological evidences; Bahia state, Brazil

\footnotetext{
* Corresponding author. Tel.: +55 71248 7812; fax: +55 712038501.

E-mailaddresses: johildo@cppg.ufba.br (J. Barbosa), martin@opgc.univ.bpclermont.fr (H. Martin), peucat@univ-rennes1.fr (J.-J. Peucat).
} 


\section{Introduction}

Dome and basin structures abundantly occur in Archean terrains: in high-grade low-level granulites as well as in low-grade high-level granite-greenstone terrains (Choukroune et al., 1995, 1997). These authors consider that during the Archaean, these structures were formed by inverse density gradients resulting in the emplacement of high density supracrustal rocks (i.e. komatiites and BIF) over a low density continental crust (i.e. TTG, tonalite-trondhjemite-granodiorite rocks), associated during the Archaean, with reheating of lower and middle crust as a consequence of magmatism and metamorphism. The temperature and plasticity increase at the deep crustal level results in diapiric ascent of plutonic rocks and in downward motion of the supracrustal formations (sagduction; Gorman et al., 1978). Consequently, most plutonites are located in domes while greenstone belts appear in basin domains as described in the Archean of the Dharwar craton in south India (Choukroune et al., 1995; Bouhallier et al., 1995; Chardon et al., 1998) or in the Baltic Shield (Martin et al., 1985; Martin, 1987). Similar structures appear in the Jequié granulitic block of the São Francisco craton (Bahia State NE Brazil)(Barbosa, 1990; Barbosa and Sabaté, 2002; Fornari and Barbosa, 1994). There, charnockitic domes are surrounded by supracrustal formations, heterogeneous granulite and enderbitic to charnockitic rocks. Although previous studies have given a good idea of the general and global evolution of the area, detailed geochronological and petrogenetic data are needed to constrain the dome emplacement timing in relation to magmatic and metamorphic events, the mechanisms of magma genesis and the possible geodynamic environment where they were emplaced. All these data are necessary in order to assess continental accretion and growth styles during the Archean and Paleoproterozoic. Consequently the purpose of this paper is: (i) to determine the age of dome formation which could be related as well as to Archaean or Palaeproterozoic and, (ii) to model the petrogenesis of the main magmatic event in the Jequié block, as well as the possible sources involved. These data will be interpreted in the light of previous works in order to discuss the genesis and geotectonic evolution of the deep crust of the São Francisco craton in Brazil.

\section{São Francisco craton}

\subsection{Major geological units}

The São Francisco craton (Almeida, 1977) is the most restudied crustal block in South America. It had been already consolidated prior to the Brasiliano (Pan African) orogenic cycle (Teixeira et al., 2000). It is limited by heterogeneous folded belts, generally of metasedimentary origin and metamorphosed under greenschist and amphibolite facies conditions. The folded belts, whose ages range from 700 to $450 \mathrm{Ma}$, are the Sergipano in the northeast, Riacho do Pontal-Rio Preto to the north, the Brasília belt to the west and the Ribeira and Araçuaí belts to the south (Fig. 1). The main part of the São Francisco craton is located in Bahia, where it consists of (i) a Mesoproterozoic sedimentary cover, deformed (Espinhaço folded belt) and Neoproterozoic sedimentary cover which remained almost undeformed during the Brasiliano orogeny and (ii) an Archean and Paleoproterozoic basement. The latter can be subdivided into four major geological units (Fig. 2): the Gavião block (GB), the Serrinha block (SB), the Jequié block (JB) and the Itabuna-Salvador-Curaçá Belt (ISCB).

The Gavião block is mainly composed of tonalitic to granodioritic orthogneiss, and gneissic-amphibolitic associations, whose ages range from 2.8 to $2.9 \mathrm{Ga}$ (Cordani et al., 1985; Marinho et al., 1994; Martin et al., 1991; Nutman and Cordani, 1993; Santos Pinto et al., 1998). Inside these formations, old TTG massifs (Sete Voltas, Boa Vista, Mata Verde) were dated between 3.4 and $3.1 \mathrm{Ga}$. They are among the oldest so far reported in South America. Additionally, old inherited zircon cores in Sete Voltas, as well as systematic 3.6 Ga Nd model ages throughout the Gavião block (Martin et al., 1997; Santos Pinto et al., 1998) favour an even older crust (up to $3.6 \mathrm{Ga}$ ) in this block. The Contendas Mirante, Umburanas (Leal et al., 2003), Riacho de Santana, Mundo Novo greenstones are located in the Gavião block. They are Archaean in age. Affected by low-grade metamorphism, they typically consist of komatiites with spinifex texture at the bottom, mafic and felsic lavas together with pyroclastic rocks in the middle and siliciclastic sediments at the top (Marinho et al., 1994; Winge, 1984; Peucat et al., 2002).

The Serrinha block is made up of banded gneiss, amphibolite and granodioritic orthogneiss 


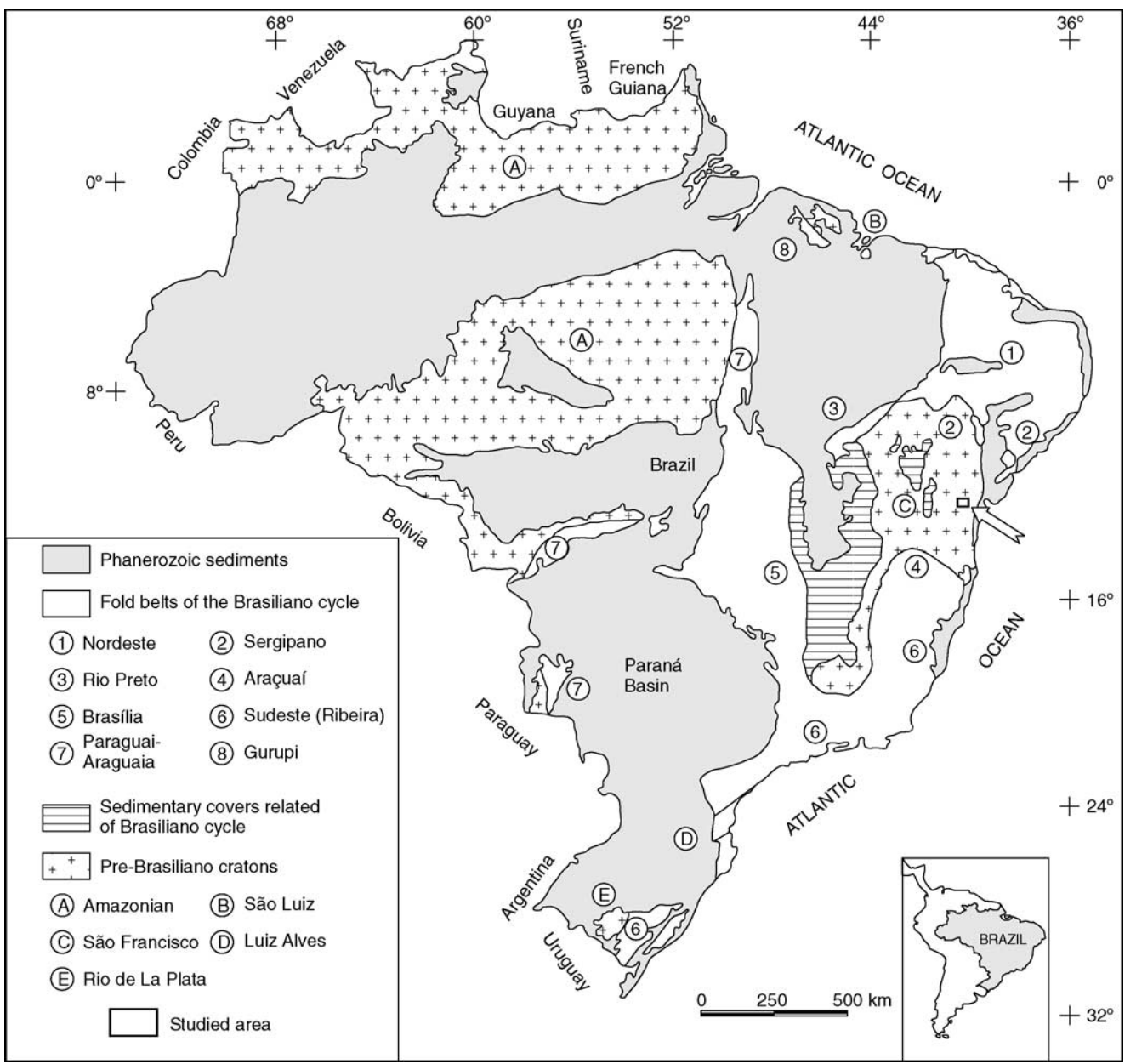

Fig. 1. Location of the studied area, of the cratons and fold belts of the Brazilian cycle (Almeida, 1977) after Schobbenhaus et al. (1984).

dated at ca $2.9 \mathrm{Ga}$ and metamorphosed under amphibolite facies conditions. The Rio Capim greenstone belt is assigned to the Archean and the Rio Itapirucu belt to the Paleoproterozoic (Winge, 1984).

The granulitic Jequié block consists of enderbite to charnockite suites (ca 2.7-2.8 Ga), heterogeneous granulites with migmatites and supracrustal rocks (Cordani, 1973; Cordani and Iyer, 1978; Barbosa, 1990).

The Salvador-Curaçá and Itabuna belts are both granulitic and consist essentially of tonalitic/ trondhjemitic rocks containing mafic and supracrustal enclaves (Barbosa, 1990).

\subsection{The southern granulitic domain}

The southern Bahia granulitic domain consists of the Jequie block to the west and the Itabuna belt to the east. They are separated by an amphibolite-facies mafic to intermediate plutonic domain, with subordinate iron formation, aluminous gneisses and garnetbearing quartzites forming the Ipiau Band (Barbosa, 1990; Barbosa et al., 1998) (Fig. 3). The Brejões and neighboring domes are located in the Jequié block. The area has been the object of many studies in recent years, which were mainly focused on determining metamorphism age and P-T conditions (Barbosa, 1988; Barbosa and Fonteilles, 1989, 1991; Iyer et al., 


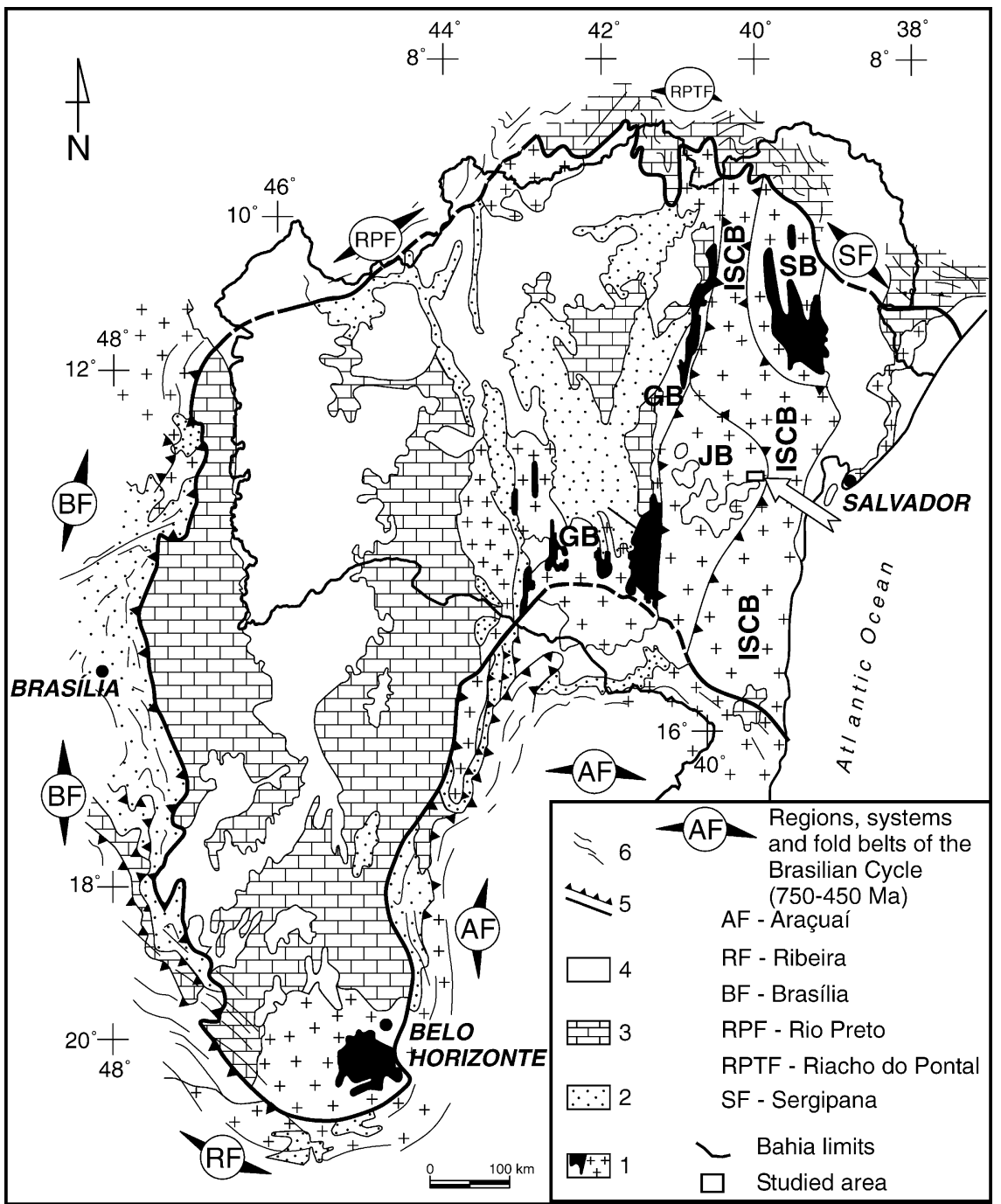

Fig. 2. Location of the studied area and geotectonic domains of São Francisco Cráton and the geotectonic domains of Bahia, Brazil: (1) Archean/Paleoproterozoic basement and the Greenstone Belts sequences, (2) Mesoproterozoic units, (3) Neoproterozoic units, (4) Phanerozoic sediments, (5) Cráton and geotectonic blocks limits, (6) Tectonic lineations. GB: Gavião block. JB: Jequié block. SB: Serrinha block. ISCB: Itabuna-Salvadoer-Curaçá block (adapted of Alkmim et al., 1993; Barbosa and Dominguez, 1996).

1995; Wilson, 1987; Figueiredo, 1989; Figueiredo and Barbosa, 1993; Marinho et al., 1994; Aillon, 1992; Arcanjo et al., 1992; Alibert and Barbosa, 1992; Fornari and Barbosa, 1994; Ledru et al., 1994; Barbosa and Sabaté, 2002).

The granulitic Jequié block (Cordani, 1973; Cordani and Iyer, 1978; Barbosa, 1990) contains important domains of charnoenderbite to charnockite (referred to as $\mathrm{CH} 1$ and $\mathrm{CH} 2$ in this paper), which intrude heterogeneous granulites (HG). The latter is associated with granulitic supracrustal rocks (SP), composed of metabasalts, quartzites, iron formations, graphitic bands and partially migmatised aluminous gneisses, the latter occasionally containing garnet and cordieritebearing anatectic granites (Fig. 4).

The Itabuna Belt is composed of homogeneous green-brown granulites of magmatic origin which follow three contrasting differentiation trends (Barbosa 


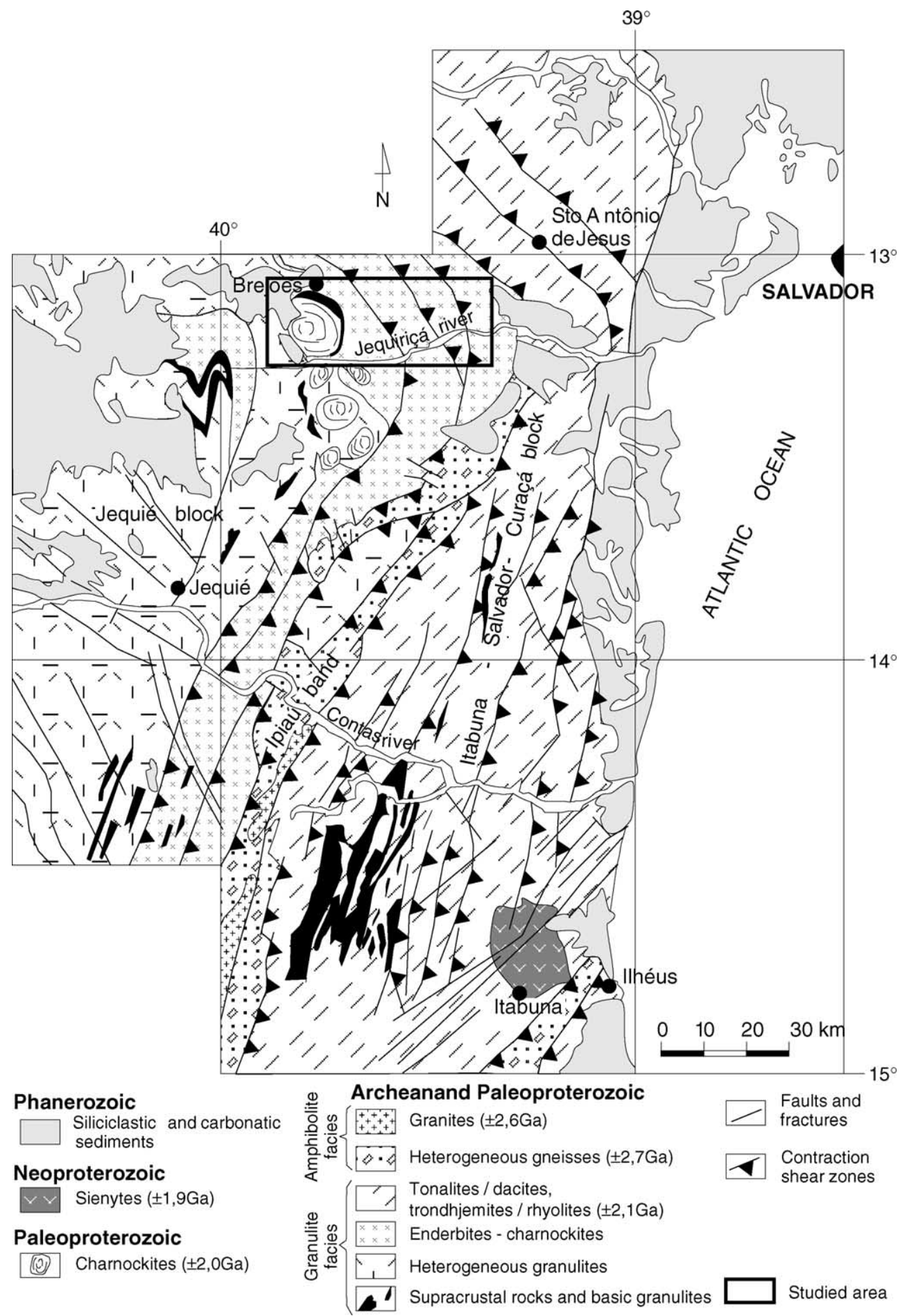

Fig. 3. Geologic sketch map of the granulite region of southern Bahia, Brazil. 


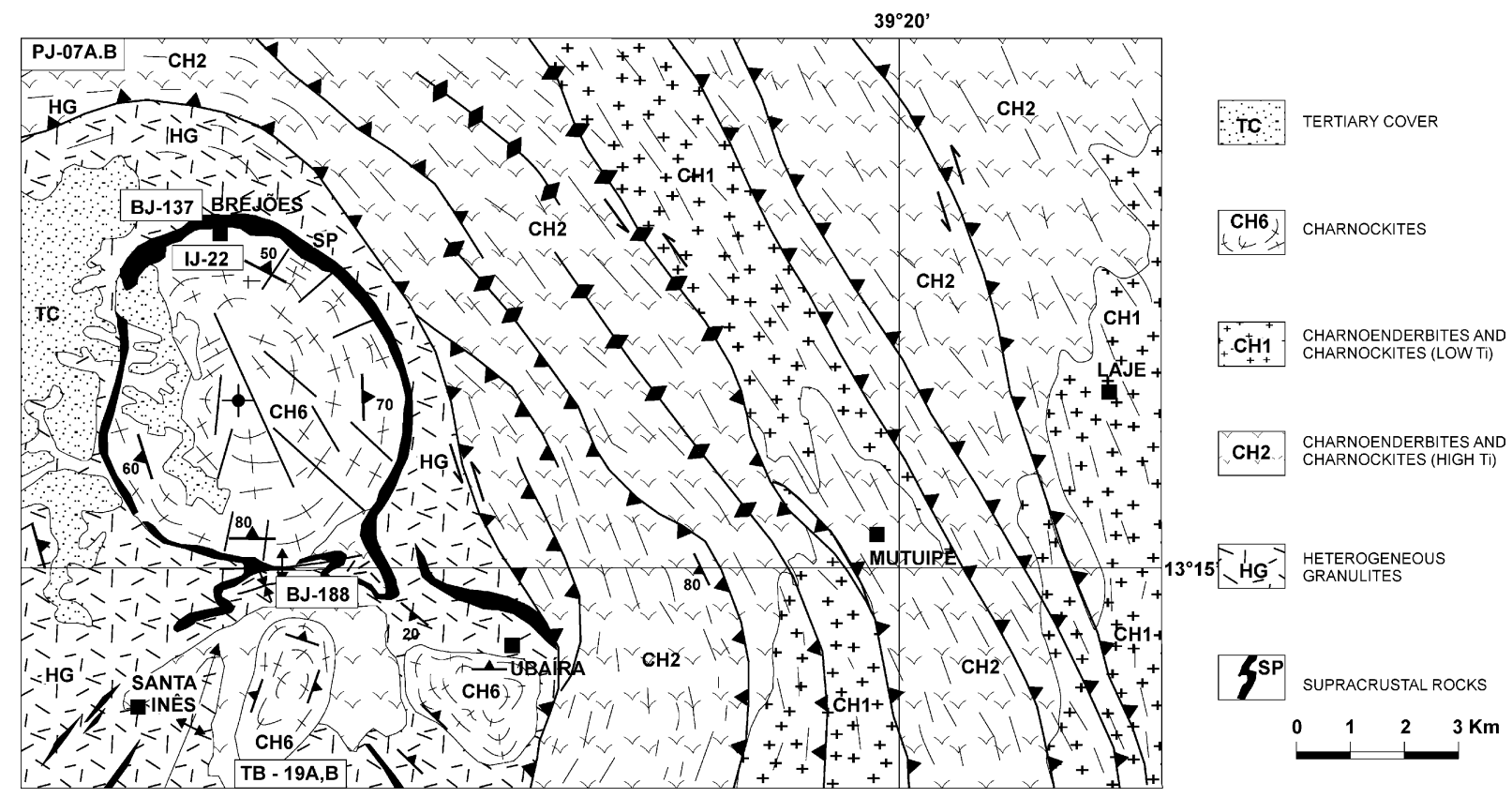

Fig. 4. Geologic sketch map of the Laje, Mutuipe, Brejões and Santa Inês area. Jequié block, Bahia, Brazil. Samples sites for geochronological study are shown.

and Fonteilles, 1989; Arcanjo et al., 1992; Oliveira et al., 1993): (i) low-K calc-alkaline (tonalite to trondjhemite), (ii) alkaline shoshonitic suite (monzonite/mangerite) and (iii) tholeiitic series (garnetbearing metagabbros or metabasalts).

The Ipiaú Band is equilibrated in the amphibolite facies and mainly consists of metagabbros and/or metabasalts intercalated with quartz feldspathic layers, granite and granodiorite plútons, meta-aluminous gneiss, banded iron formation and garnet-bearing quartzite.

These units record at least three episodes of ductile deformation, contemporaneous with the Paleoproterozoic (ca $2.0 \mathrm{Ga}$ ) high-grade metamorphism (Wilson, 1987; Ledru et al., 1994). The first episode is characterized by a flat foliation associated with large, recumbent folds. The second episode is coaxial with the first but consists of folds with sub-vertical axial planes, which are more open in the Jequié block than in the Itabuna belt. The third episode is characterised by vertical foliation with sub horizontal lineation. These data, together with sigmoïdal-splayed minerals, indicate a movement from SW toward NE
(Fig. 3). Retrograde mineral assemblages, associated with shear zones, have been interpreted as reactivated by the ascent of granulite from the lower crust. Barbosa (1990) and Barbosa and Fonteilles (1991) calculated minimum pressures of 5-7 kbar and temperatures of $850-870^{\circ} \mathrm{C}$ for the granulitic metamorphism. Figueiredo (1989) and Barbosa (1990) proposed a geotectonic model in which the Itabuna belt is considered as an island arc or a continental magmatic arc margin, the Jequié block being a micro-continent. The possible island arc has been thrusted over the Jequié continent during arc-continent collision.

\section{Geological setting of the Brejões-Santa Inês area}

The study area is located near Brejões, Santa Inês, Mutuipe and Laje cities where six major dome structures are recognised (Fig. 3). The country rocks of the domes consist of four distinct granulite types (SP, $\mathrm{HG}, \mathrm{CH} 1$ and $\mathrm{CH} 2$ in chronological order) (Barbosa et al., 1998). A set of CH6 charnockites is intrusive 
in the previous ones and only found within the domes (Fig. 4).

\subsection{Supracrustal formations (SP)}

In the supracrustal formation (SP) on detach kinzigitic gneisses, andesitic metabasalts, banded iron formations, garnet-free or garnet-bearing quartzite and quartz feldspathic layers. All these rocks were deformed and reequilibrated in granulite facies conditions. Most of mineral parageneses formed during metamorphism peak. However, some minor phases such as biotite and hornblende, which crystallised as rim around ferro-magnesian and opaque minerals, are considered as retromorphic. SP defines a spectacular rim that lines the Brejões dome, and is located between the $\mathrm{CH} 6$ charnockites (Fig. 4) and the heterogeneous granulites (HG). They display a centimetre-scale tectonic banding, and the whole thickness not exceeding $100 \mathrm{~m}$. The kinzigitic gneisses display a medium to coarse-grained granoblastic texture with irregular contacts between grains. They consist in garnet (35\%), quartz $(30 \%)$, plagioclase $(15 \%)$, cordierite $(10 \%)$, and biotite (5\%) (Table 1). These kinzigitic gneisses $(1-5 \mathrm{~m})$ are alternating with quartzo-feldspathic and quartzite layers $(5-10 \mathrm{~m})$, which very often, are cut by centimetric veins of quartzo-feldspathic pagmatoids. The associated garnet-cordierite charnockite are produced by partial melting of the kinzigitic rocks (Table 1). The andesitic metabasalts which are intercalated in supracrustal rocks, and are dark green and strongly foliated with a fine-grained granoblastic texture. The main metamorphic minerals of these rocks are plagioclase, orthopyroxene, clinopyroxene, and brown hornblende; opaque mineral and apatite are accessory phases. Biotite and green hornblende are retromorphic minerals (Table 1). The banded iron formations are located to the north, are made up of hematite, magnetite (70-90\%) and quartz (5-10\%) (Table 1) with granoblastic texture. The garnet-free or garnetbearing quartzites, when fresh are light grey, medium to coarse-grained rocks. They exhibit penetrative foliation defined by garnet and orthopyroxene orientation. Table 1 summarises the main metamorphic parageneses of these quartzites. The quartz feldspathic layers with graphic texture consists of quartz and mesoperthite as main minerals and biotite, garnet, orthopyroxene and opaque minerals as accessory phases (Table 1).

\subsection{Heterogeneous granulite $(H G)$}

Heterogeneous granulites mainly consist of dark green granulites with charnockitic characteristics that commonly contain boudins and enclaves of metagabbros, quartz feldspathic layers and supracrustal rocks (Barbosa et al., 1998). The heterogeneous granulites had as protolith plutonic rocks of amphibolite facies that were transformed to granulites by the regional metamorphism. They are medium-to coarse-grained rocks containing 40-50\% mesoperthite, 30\% quartz, $10 \%$ antiperthitic plagioclase, $10 \%$ orthopyroxene and 2-7\% clinopyroxene (Table 1). In various places they show evidence of migmatization with orthopyroxene bearing neosome. Metagabbro enclaves are made up of plagioclase, hornblende, orthopyroxene and clinopyroxene. Some display orthopyroxene-rich rims surrounding amphibole rich cores interpreted as reflecting prograde metamorphism. The observed reaction is: hornblende + quartz $=$ plagioclase + orthopyroxene \pm clinopyroxene $+\mathrm{H}_{2} \mathrm{O}$ where the left and right sides respectively represent amphibolite and granulite facies parageneses (Barbosa, 1990).

\subsection{The CH1 Laje charnoenderbite to charnockite suite}

Generally, the CH1 are strongly deformed and recrystalised (Fornari and Barbosa, 1994), but in some places a mesoperthitic phenoclastic coarse-grained texture is preserved. In addition to mesoperthite the $\mathrm{CH} 1$ consists of a medium-grained assemblage of quartz, antiperthitic plagioclase, orthopyroxene, clinopyroxene and high titanium biotite, all these minerals belonging to metamorphic paragenese. Locally, they show evidence of retromorphic metamorphism; expressed by the crystallisation of low-Ti biotite, muscovite, sericite and bastite as well as of a second generation of very small plagioclase and microcline grains. Accessories are ilmenite, magnetite, apatite and zircon (Table 1).

\subsection{The CH2 Mutuipe charnoenderbite to charnockite suite}

In several aspects the $\mathrm{CH} 2$ are similar to $\mathrm{CH} 1$ except that they contain brown-green hornblende as 
Table 1

Typical mineralogical compositions of rocks from Laje (CH1), Mutuipe (CH2), Brejões and Santa Inês (CH6)

\begin{tabular}{|c|c|c|c|}
\hline Rocks & $\begin{array}{l}\text { Major metamorphic minerals } \\
\text { (modal composition) }\end{array}$ & Accessory minerals & Retrograde metamorphic minerals \\
\hline \multicolumn{4}{|l|}{ First group (SP) } \\
\hline Kinzigitic gneiss & $\begin{array}{l}\text { Gt (35\%); Qz (30\%); Plag } \\
(15 \%) ; \mathrm{Cd}(10 \%) ; \mathrm{Bi}(5 \%) \text {; } \\
\text { Sill(5\%) }\end{array}$ & Op; Zr; Mz; Gf; Sp; Mp; Opx & $\mathrm{Bi}$ \\
\hline Andesitic metabasalts & $\begin{array}{l}\text { Plag (40\%); Cpx (25\%); Opx } \\
(20 \%) ; \mathrm{Hb}(10 \%) ; \mathrm{Qz}(4 \%)\end{array}$ & Op; Ap & $\mathrm{Bi} ; \mathrm{Hb}$ \\
\hline Banded iron formation & $\begin{array}{l}\mathrm{He} / \mathrm{Mt}(70-90 \%) ; \mathrm{Qz} \\
(30-10 \%)\end{array}$ & & \\
\hline Quartettes/Garnet quartettes & $\begin{array}{l}\text { Qz (60-90\%); Gt (5-10\%); } \\
\text { Plag (1-5\%); Opx; Bi. }\end{array}$ & Op & $\mathrm{Se} ; \mathrm{Bi}$ \\
\hline Quarteo feldspathic band & $\begin{array}{l}\text { Q2 (50\%); Mp (40\%); Plag } \\
(8-10 \%)\end{array}$ & Op; Opx; Bi; Gt & $\mathrm{Se}$ \\
\hline Garnet—cordierite Charnockites & $\begin{array}{l}\text { Mp (50-60\%); Qz (10-20\%); } \\
\text { Plag (10-20\%) Cd (5\%); Gt } \\
(5 \%) ; \text { Opx; Bi }\end{array}$ & $\mathrm{Op} ; \mathrm{Zr} ; \mathrm{Mz}$ & Se; Mir \\
\hline \multicolumn{4}{|l|}{ Second group (HG) } \\
\hline Heterogeneous granulites & $\begin{array}{l}\text { Mp (40-50\%); Qz (30\%); } \\
\text { Plag (10\%) (An23); Opx } \\
(10 \%) ; \text { Cpx (2-7\%); Hb; Bi }\end{array}$ & $\mathrm{Op} ; \mathrm{Zr} ; \mathrm{Ap}$ & Hb; Bi; Mic; Rag; Cln; Bt; Mir \\
\hline Quarteo feldspathic veins & $\begin{array}{l}\text { Mp (50-60\%); Qz (20-30\%); } \\
\text { Plag (5\%) (An25-30); Opx; } \\
\text { Cpx; Hb; Bi }\end{array}$ & $\mathrm{Op} ; \mathrm{Zr}$ & $\mathrm{Hb} ; \mathrm{Bi} ; \mathrm{Clr}$ \\
\hline Metagabbros & $\begin{array}{l}\text { Plag }(40-50 \%) \text { (An 30-35); } \\
\text { Hb (30-35\%); Opx; Cpx } \\
(25-30 \%)\end{array}$ & $\mathrm{Op} ; \mathrm{Ap} ; \mathrm{Zr} ; \mathrm{Qz}$ & $\mathrm{Hb} ; \mathrm{Bi}$ \\
\hline \multicolumn{4}{|l|}{ Third group (CH1) } \\
\hline Charnoenderbites & $\begin{array}{l}\text { Plag }(50 \%)(\operatorname{An} 30) ; \mathrm{Qz} \\
(7-15 \%) ; \mathrm{Cpx}(2-5 \%) ; \text { Opx } \\
(5-10 \%) ; \mathrm{Mp}(10-12 \%)\end{array}$ & $\mathrm{Op} ; \mathrm{Zr} ; \mathrm{Ap} ; \mathrm{Mz}$ & Plag; Mu; Se; Bt; Mir \\
\hline Charnockites & $\begin{array}{l}\text { Mp (40-50\%); Qz (30\%); } \\
\text { Plag (10\%)(An23); Opx } \\
(10 \%) ; \mathrm{Cpx}(2 \%) ; \mathrm{Bi}\end{array}$ & Op; Zn Ap; Mz & Mic; Plag; Cln Bt; Mir \\
\hline \multicolumn{4}{|l|}{ Fourth group $(\mathrm{CH} 2)$} \\
\hline Charnoenderbites & $\begin{array}{l}\text { Plag }(40 \%)(\operatorname{An} 40) ; \mathrm{Mp} \\
(3-15 \%) ; \mathrm{Hb}(10 \%) ; \mathrm{Qz} \\
(10-15) ; \mathrm{Opx}(1-6 \%) ; \mathrm{Cpx} \\
(3-4 \%) ;\end{array}$ & $\mathrm{Op} ; \mathrm{Ap} ; \mathrm{ZnMz}$ & Plag; Mu; Se; Bt; Mir \\
\hline Charnockites & $\begin{array}{l}\text { Mp (30-35\%); Plag } \\
(10-20 \%)(\text { An } 27) ; \mathrm{Hb}(10 \%) ; \\
\text { Qz (30\%); Opx (5\%); Cpx } \\
(2 \%) ; \mathrm{Bi}\end{array}$ & $\mathrm{Op} ; \mathrm{Zr} ; \mathrm{Ap}$ & $\mathrm{Bi} ; \mathrm{Se} ; \mathrm{Cin} \mathrm{Bt}$ \\
\hline \multicolumn{4}{|l|}{ Fifth group (CH6) } \\
\hline Charnockites & $\begin{array}{l}\mathrm{Mp}(30-40 \%) ; \text { Plag } \\
(30 \%)(\operatorname{An} 25) ; \text { Opx }(5-10 \%) \\
\text { Cpx }(2-5 \%) ; \mathrm{Hb}(10 \%) ; \mathrm{Qz} \\
(20 \%)\end{array}$ & Op;Zr;Ap & $\mathrm{Bi} ; \mathrm{Se} ; \mathrm{Clr} ; \mathrm{Bt}$ \\
\hline
\end{tabular}

Abbreviations: Opx: Orthopyroxene; Cpx: Clinopyroxene; Plag: plagioclase; Mp: mesoperthite; Hb: Hornblende; Bi: Biotite; Qz: quartz; Gt: garnet; Cd: cordierite; Sill: sillimanite; Mic: microcline; Op: opaque minerals; Zr: zircon; Ap: apatite; Gf: Graphite; Clr: chlorite; Mu: Muscovite; Se: Sericite; Bt: bastite; Mir: myrmeckrte; Epi: epidote; Tr: Tremolite; Sp: spinel; He/Mt: hematite/magnetite; An: (anorthite percentage); Mz: monazite. 
well as larger amounts of opaque minerals (Table 1). They also contain mafic enclaves, stretched out parallel to the general banding. Quartz and pegmatitic veins are parallel or at a low angle to the banding and foliation. Fluid inclusions in quartz crystals from these veins indicate that low-density $\left(0.85 \mathrm{~g} \mathrm{~cm}^{-3}\right)$ $\mathrm{CO}_{2}$-rich synmetamorphic fluid percolated through these rocks (Xavier et al., 1989). Thermo-barometric studies indicate that these fluids equilibrated at the same pressure and temperature as those of granulitic metamorphism. Both $\mathrm{CH} 1$ and $\mathrm{CH} 2$ are considered as intrusive into the heterogeneous granulites (HG).

\subsection{The CH6 charnockites synchronous to doming}

The CH6 charnockites is restricted to the central part of the domes (Fig. 4). It is heterogeneously deformed, with undeformed domains and includes angular xenoliths of the surrounding rocks $(\mathrm{HG}, \mathrm{CH} 1$ and $\mathrm{CH} 2$ ), thus demonstrating their intrusive character into these rocks. CH6 consists of green coarsegrained charnockites, with mineralogy essentially plutonic composed by mesoperthite (30-40\%), quartz (20\%), hornblende (10\%), antiperthitic plagioclase, $\mathrm{An}_{25}$ (30\%), orthopyroxene (5\%) and clinopyroxene $(2-5 \%)$ (Table 1). Accessory minerals are opaques, apatite and zircon. Mesoperthite and brown hornblende phenocrysts give a patchy aspect to the rock. In some places bastitized orthopyroxene cores are surrounded by hornblende rims that suggest retrometamorphism. Quartz and pegmatite veins are widespread whereas rare garnet crystals are considered as resulting from magma contamination by aluminous supracrustals.

Except for works of Miranda et al. (1983) and Barbosa (1990), who interpreted the elliptical structure of the dome as due to tectonic interference, no detailed structural work has been performed in this area. In Fig. 4, the Brejões dome shows foliation dipping outwards, except on its south side, where it dips toward the core. The supracrustal formations are compressed between the Brejões and Santa Ines domes to the north and to the south, respectively. Brejões dome is heterogeneously deformed; its rim shows high strain with typical C/S vertical structures, whereas in the core the foliation becomes subhorizontal, and rocks are very homogeneous.

\section{Whole rock $\mathrm{Rb}-\mathrm{Sr}$ and $\mathrm{Sm}-\mathrm{Nd}$ isotope data, ${ }^{207} \mathrm{~Pb} /{ }^{206} \mathrm{~Pb}$ TIMS evaporation zircon and monazite ages}

Previous $\mathrm{Rb}-\mathrm{Sr}, \mathrm{U}-\mathrm{Pb}, \mathrm{Pb}-\mathrm{Pb}$ and $\mathrm{K}-\mathrm{Ar}$ ages allowed to show the occurrence of Archean magmatic suites formed ca 2.7-2.9 Ga and of a high grade metamorphic event ca 2.0-2.1 Ga in the Jequié block (Cordani, 1973; Cordani and Iyer, 1978; Mascarenhas and Garcia, 1986; Wilson, 1987; Alibert and Barbosa, 1992; Marinho et al., 1994; Silva et al., 2002). Main results related to the Brejões area are summarised below.

\subsection{Previous work}

Marinho et al. (1994) reported a $3.2 \mathrm{Ga} \mathrm{Nd}$ model age for supracrustal garnet-cordierite-bearing charnockite between Brejões and Santa Inês domes. Heterogeneous granulites from south of the Brejões dome provided a 4-point $\mathrm{Rb}-\mathrm{Sr}$ isochron age at $2699 \pm 24 \mathrm{Ma}$ (Wilson, 1987) and Nd model ages between 2.6 to $3.3 \mathrm{Ga}$ (Marinho et al., 1994; Wilson, 1987) that corroborate the Archaean age of the protoliths. On the other hand, heterogeneous granulites gave $\mathrm{Rb}-\mathrm{Sr}$ and $\mathrm{Pb}-\mathrm{Pb}$ isochron ages around $2.0 \mathrm{Ga}$ which are interpreted as metamorphic ages (Wilson, 1987). Farther east, the Laje charnoenderbite CH1 (Fig. 4) yielded a $\mathrm{Rb}-\mathrm{Sr}$ whole rock isochron age of $2932 \pm 124 \mathrm{Ma}$ and $\mathrm{Nd}$ model ages between 3.0 and $3.15 \mathrm{Ga}$ (Wilson, 1987). A zircon SHRIMP age at $2810 \mathrm{Ma}$ (Alibert and Barbosa, 1992) is interpreted as that of magmatic emplacement of the protoliths. The Mutuipe charnoenderbite $\mathrm{CH} 2$ (Fig. 4) provides the same Rb-Sr $(2894 \pm 130 \mathrm{Ma})$ and $\mathrm{Sm}-\mathrm{Nd}$ results (ca 3.0 Ga) as $\mathrm{CH} 1$ (Wilson, 1987) (Table 2). $\mathrm{Pb}-\mathrm{Pb}$ whole rock isochrone yields an age of $3432 \pm 48 \mathrm{Ma}$ that has been considered as an artefact (Wilson, 1987). Zircon SHRIMP dating (Alibert and Barbosa, 1992) provided an age of $2689 \pm 1 \mathrm{Ma}$ which is slightly younger than that obtained by the same method for CH1. Another SHIMP zircon dating of a Jequié charnockite defines a magmatic age of $2473 \pm 5 \mathrm{Ma}$ with metamorphic overgrowths at $2061 \pm 6 \mathrm{Ma}$ in the south of the Brejões area (Silva et al., 2002). No data from (CH6) charnockites are available, as yet except a $\mathrm{Nd}$ model age at $3.2 \mathrm{Ga}$ (Wilson, 1987) (Tables 2 and 3). 
Table 2

Whole rock $\mathrm{Sm}-\mathrm{Nd}$ and $\mathrm{Rb}-\mathrm{Sr}$ results for the granulites

\begin{tabular}{|c|c|c|c|c|c|c|c|c|c|c|c|c|c|c|c|c|}
\hline Samples & $\begin{array}{l}\text { Sm } \\
(\mathrm{ppm})\end{array}$ & $\begin{array}{l}\mathrm{Nd} \\
(\mathrm{ppm})\end{array}$ & ${ }^{147} \mathrm{Sm} /{ }^{144} \mathrm{Nd}$ & ${ }^{143} \mathrm{Nd} /{ }^{144} \mathrm{Nd}$ & $\begin{array}{l}\text { Error } 2 \sigma \mathrm{m} \\
\times 10^{-6} \\
\end{array}$ & $\varepsilon_{\mathrm{Nd}} 0 \mathrm{Ga}$ & $\begin{array}{l}\text { TDM (1) Ga } \\
\left(\varepsilon_{0}=+10\right) \\
\end{array}$ & $\begin{array}{l}\mathrm{TDM}(2) \mathrm{Ga} \\
\left(\varepsilon_{0}=+8\right)\end{array}$ & $\varepsilon_{\mathrm{Nd}} 2.1 \mathrm{Ga}$ & $\varepsilon_{\mathrm{Nd}} 2.7 \mathrm{Ga}$ & $\begin{array}{l}\mathrm{Rb} \\
(\mathrm{ppm})\end{array}$ & $\begin{array}{l}\mathrm{Sr} \\
(\mathrm{ppm})\end{array}$ & ${ }^{87} \mathrm{Rb} /{ }^{86} \mathrm{Sr}$ & ${ }^{87} \mathrm{Sr} r^{86} \mathrm{Sr}$ & $\begin{array}{l}\text { Error } 2 \sigma \mathrm{m} \\
\times 10^{-6} \\
\end{array}$ & $\mathrm{ISr} 2.1 \mathrm{Ga}$ \\
\hline \multicolumn{17}{|c|}{ Supracrustal rocks (SP) } \\
\hline BJ-137 & 9.3 & 70.3 & 0.0803 & 0.510536 & 7 & -41 & 2.97 & 2.86 & -10 & -0.9 & 135 & 301 & 1.31 & 0.75160 & 15 & 0.712 \\
\hline 1263PJR05(6) ${ }^{\mathrm{a}}$ & 4.8 & 28.6 & 0.1016 & 0.51073 & - & -37 & 3.26 & 3.13 & -12 & -4.4 & & & & & & \\
\hline \multicolumn{17}{|c|}{ Heterogeneous granulites (HG) } \\
\hline PJ-07-B & 0.67 & 5.33 & 0.0755 & 0.510506 & 8 & -42 & 2.90 & 2.79 & -9.2 & 0.1 & 162 & 257 & 1.83 & 0.76491 & 27 & 0.709 \\
\hline BJ-188 & 22.3 & 131 & 0.1029 & 0.510782 & 6 & -36 & 3.23 & 3.10 & -11 & -3.9 & 117 & 196 & 1.74 & 0.78663 & 20 & 0.734 \\
\hline PJ-07-A & 6.48 & 48.9 & 0.0801 & 0.510558 & 9 & -41 & 2.94 & 2.82 & -9.4 & -0.4 & 153 & 149 & 3.01 & 0.79334 & 25 & 0.702 \\
\hline TB19B & 11.1 & 58.8 & 0.1144 & 0.511051 & 3 & -31 & 3.20 & 3.05 & -8.9 & -2.6 & - & - & - & - & - & \\
\hline $17 \mathrm{~d}^{\mathrm{b}}$ & 4.2 & 28.9 & 0.0886 & 0.51068 & - & -38 & 2.99 & 2.87 & -9.3 & -1.0 & 94 & 138 & 1.98 & 0.79027 & - & 0.730 \\
\hline $16 b^{b}$ & 12.3 & 63.6 & 0.1079 & 0.51088 & - & -34 & 3.25 & 3.11 & -11 & -3.8 & 129 & 185 & 2.04 & 0.79857 & - & 0.737 \\
\hline \multicolumn{17}{|c|}{ Charnoenderbite-charnockite (CH1) } \\
\hline $1^{\mathrm{b}}$ & 1.9 & 10.5 & 0.1119 & 0.51104 & - & -31 & 3.13 & 2.99 & -8.4 & -2.0 & 43 & 668 & 0.2 & 0.70900 & - & 0.703 \\
\hline $13^{\mathrm{b}}$ & 1.8 & 10.5 & 0.1061 & 0.51085 & - & -35 & 3.24 & 3.10 & -11 & -3.8 & 79 & 375 & 0.6 & 0.72846 & - & 0.710 \\
\hline $10^{\mathrm{b}}$ & 6.7 & 36.0 & 0.1116 & 0.51105 & - & -31 & 3.11 & 2.97 & -8.2 & -1.7 & 256 & 76 & 9.7 & 1.11496 & - & 0.820 \\
\hline \multicolumn{17}{|c|}{ Charnoenderbite-charnockite (CH2) } \\
\hline $4^{\mathrm{b}}$ & 9.0 & 60.7 & 0.0900 & 0.51064 & - & -39 & 3.08 & 2.96 & -11 & -2.3 & 70 & 288 & 0.7 & 0.73527 & - & 0.714 \\
\hline $6^{\mathrm{b}}$ & 12.1 & 65.9 & 0.1109 & 0.51103 & - & -31 & 3.12 & 2.97 & -8.4 & -1.8 & 84 & 240 & 1.0 & 0.74493 & - & 0.714 \\
\hline $21^{\mathrm{b}}$ & 15.7 & 88.9 & 0.1066 & 0.51102 & - & -32 & 3.01 & 2.87 & -7.4 & -0.5 & 193 & 160 & 3.5 & 0.84905 & - & 0.743 \\
\hline $23 \mathrm{a}^{\mathrm{b}}$ & 10.7 & 63.6 & 0.1015 & 0.510920 & - & -34 & 3.01 & 2.88 & -8.0 & -0.8 & 406 & 86 & 13.7 & 1.27870 & - & 0.865 \\
\hline \multicolumn{17}{|c|}{ Charnockites (CH6) } \\
\hline $\mathrm{IJ}-22$ & 15.2 & 82.3 & 0.1114 & 0.510956 & 5 & -33 & 3.25 & 3.10 & -10 & -3.5 & 208 & 70 & 8.92 & 1.04319 & 21 & 0.773 \\
\hline TB19A & 18.53 & 138 & 0.0811 & 0.510590 & 3 & -40 & 2.92 & 2.81 & -9 & -0.2 & & & & & & \\
\hline $14^{\mathrm{b}}$ & 11.8 & 61.9 & 0.1157 & 0.51109 & - & -30 & 3.18 & 3.03 & -8.5 & -2.3 & 377 & 67 & 16.3 & 1.37384 & - & 0.881 \\
\hline
\end{tabular}

${ }^{a}$ Data from Marinho et al. (1994).

b Data from Wilson (1987). 
Table 3

Summary of zircon and monazite ${ }^{207} \mathrm{~Pb} /{ }^{206} \mathrm{~Pb}$ ages from evaporation obtained by thermo-ionisation mass spectrometer (TIMS)

\begin{tabular}{|c|c|c|c|c|c|c|c|c|c|}
\hline Samples & Step (A) & $\begin{array}{l}n \text { ratios } \\
\text { measured }\end{array}$ & ${ }^{206} \mathrm{~Pb} /{ }^{204} \mathrm{~Pb}$ & ${ }^{207} \mathrm{~Pb} /{ }^{206} \mathrm{~Pb}$ & $\begin{array}{l}\text { Error } 2 \sigma \mathrm{m} \\
\times 10^{-4}\end{array}$ & $\begin{array}{l}{ }^{207} \mathrm{~Pb} /{ }^{206} \mathrm{~Pb} \\
\text { corrected }\end{array}$ & $\begin{array}{l}{ }^{207} \mathrm{~Pb} /{ }^{206} \mathrm{~Pb} \\
(\mathrm{Ma})\end{array}$ & $\begin{array}{l}2 \times \text { error } \\
\text { probable }(\mathrm{Ma})\end{array}$ & $\begin{array}{l}\text { S.D. } \\
\text { (Ma) }\end{array}$ \\
\hline \multicolumn{10}{|c|}{ BJ 137: garnet-cordierite bearing charnockite (SP) } \\
\hline \multirow[t]{2}{*}{ Zircon } & 2.6 & 40 & 1708 & 0.1300 & 2 & 0.1222 & 1989 & 3 & 8 \\
\hline & $2.6^{\mathrm{a}}$ & 12 & 2853 & 0.1368 & 21 & 0.1322 & 2127 & 28 & 48 \\
\hline \multicolumn{10}{|l|}{ Monazite } \\
\hline \multirow[t]{2}{*}{10 grains } & $3.1^{\mathrm{a}}$ & 20 & 9302 & 0.1286 & 10 & 0.1272 & 2060 & 13 & 30 \\
\hline & 2.4 & 20 & 4207 & 0.1300 & 4 & 0.1269 & 2055 & 6 & 13 \\
\hline 3 grains & 2.7 & 20 & 7826 & 0.1280 & 4 & 0.1263 & 2047 & 5 & 11 \\
\hline \multirow[t]{2}{*}{3 grains } & $2.4^{\mathrm{a}}$ & 20 & 1914 & 0.1330 & 15 & 0.1261 & 2044 & 22 & 49 \\
\hline & & & & & & Mean & 2052 & 2 & 7 \\
\hline \multicolumn{10}{|c|}{ BJ 188: heterogeneous granulite (HG) } \\
\hline \multicolumn{10}{|c|}{ Zircon } \\
\hline \multirow[t]{4}{*}{ Grain 3} & 2.6 & 20 & 855 & 0.1793 & 5 & 0.1646 & 2504 & 5 & 11 \\
\hline & 2.6 & 20 & 1631 & 0.1766 & 2 & 0.1690 & 2548 & 2 & 4 \\
\hline & $2.6^{\mathrm{a}}$ & 160 & 2987 & 0.1744 & 1 & 0.1702 & 2560 & 1 & 9 \\
\hline & $2.6^{\mathrm{a}}$ & 140 & 3150 & 0.1739 & 1 & 0.1699 & 2557 & 1 & 6 \\
\hline \multirow[t]{3}{*}{ Grain 4} & 2.6 & 20 & 1257 & 0.1706 & 2 & 0.1605 & 2461 & 2 & 4 \\
\hline & 2.6 & 20 & 1544 & 0.1692 & 2 & 0.1618 & 2475 & 2 & \\
\hline & 2.8 & 40 & 4168 & 0.1690 & 8 & 0.1659 & 2517 & 8 & 25 \\
\hline \multicolumn{10}{|c|}{ TB19 B: heterogeneous granulite (HG) } \\
\hline \multicolumn{10}{|l|}{ Zircon } \\
\hline 1 grain & 2.6 & 140 & 5197 & 0.1619 & 2 & 0.1595 & 2450 & 2 & 9 \\
\hline \multicolumn{10}{|c|}{ PJ 07 B: heterogeneous granulite (HG) } \\
\hline \multicolumn{10}{|c|}{ Monazite } \\
\hline 10 grains & $2.5^{\mathrm{a}}$ & 60 & 10723 & 0.1273 & 1 & 0.1263 & 2047 & 2 & 6 \\
\hline \multicolumn{10}{|c|}{ PJ 07 A: heterogeneous granulite (HG) } \\
\hline \multicolumn{10}{|c|}{ Monazite } \\
\hline 10 grains & $2.8^{\mathrm{a}}$ & 20 & 76951 & 0.1261 & 1 & 0.1261 & 2044 & 1 & 2 \\
\hline \multicolumn{10}{|c|}{ IJ 22: charnockite (CH6) } \\
\hline \multicolumn{10}{|l|}{ Zircon } \\
\hline \multirow[t]{2}{*}{1 grain } & 2.8 & 20 & 1417 & 0.1478 & 3 & 0.1388 & 2212 & 3 & 7 \\
\hline & $3.1^{\mathrm{a}}$ & 60 & 2888 & 0.1587 & 2 & 0.1544 & 2396 & 2 & 9 \\
\hline 7 grains & 3.1 & 20 & 1742 & 0.1762 & 4 & 0.1691 & 2549 & 4 & 8 \\
\hline \multirow[t]{3}{*}{1 grain } & 2.6 & 40 & 3892 & 0.1653 & 4 & 0.1621 & 2478 & 1 & 4 \\
\hline & $2.6^{\mathrm{a}}$ & 180 & 3543 & 0.1636 & 26 & 0.1600 & 2456 & 4 & 28 \\
\hline & $2.6^{\mathrm{a}}$ & 140 & 3858 & 0.1637 & 1 & 0.1604 & 2460 & 1 & 8 \\
\hline \multirow[t]{3}{*}{1 grain } & 2.4 & 80 & 1479 & 0.1462 & 3 & 0.1374 & 2195 & 1 & 4 \\
\hline & 2.6 & 180 & 11722 & 0.1578 & 3 & 0.1567 & 2420 & 3 & 19 \\
\hline & 2.8 & 40 & 2286 & 0.1610 & 5 & 0.1555 & 2407 & 5 & 16 \\
\hline
\end{tabular}

TB 19 A: charnockite (CH6)

\section{Zircon}

$\begin{array}{llllllllll}1 \text { grain } & 2.6 & 13 & 10865 & 0.1335 & 39 & 0.1323 & 2129 & 29 & 52 \\ & 2.8 & 80 & 39966 & 0.1417 & 2 & 0.1414 & 2245 & 3 & 12 \\ 1 \text { grain } & 2.8 & 20 & 5956 & 0.1270 & 4 & 0.1248 & 2026 & 6 & 13 \\ & 3.0 & 20 & 4803 & 0.1312 & 11 & 0.1285 & 2078 & 15 & 34 \\ 1 \text { grain } & 2.7 & 80 & 12036 & 0.1334 & 2 & 0.1323 & 2129 & 3\end{array}$


Table 3 (Continued)

\begin{tabular}{rlllllllll}
\hline Samples & Step (A) & $\begin{array}{l}n \text { ratios } \\
\text { measured }\end{array}$ & ${ }^{206} \mathrm{~Pb} /{ }^{204} \mathrm{~Pb}$ & ${ }^{207} \mathrm{~Pb} /{ }^{206} \mathrm{~Pb}$ & $\begin{array}{l}\text { Error } 2 \sigma \mathrm{m} \\
\times 10^{-4}\end{array}$ & $\begin{array}{l}{ }^{207} \mathrm{~Pb} /{ }^{206} \mathrm{~Pb} \\
\text { corrected }\end{array}$ & $\begin{array}{l}{ }^{207} \mathrm{~Pb} /{ }^{206} \mathrm{~Pb} \\
(\mathrm{Ma})\end{array}$ & $\begin{array}{l}2 \times \mathrm{error} \\
\text { probable }(\mathrm{Ma})\end{array}$ & $\begin{array}{l}\mathrm{S} . \mathrm{D} . \\
(\mathrm{Ma})\end{array}$ \\
\hline $\begin{array}{rllllllll}\text { Monazite } \\
1 \text { grain }\end{array}$ & 2.4 & 40 & 969 & 0.1382 & 9 & 0.1245 & 2022 & 13 \\
& 2.7 & 20 & 4025 & 0.1281 & 4 & 0.1248 & 2026 & 6 & 39 \\
1 grain & 2.7 & 20 & 621 & 0.1465 & 8 & 0.1251 & 2030 & 31 & 4 \\
& & & & & & Mean & 2026 & 1 & 43 \\
\hline
\end{tabular}

${ }^{a}$ Indicates ratios measured by Faraday cups, other ratios are from ion-counting system.

\subsection{Analytical methods and new data}

$\mathrm{Sr}$ and Nd whole rock isotopes, zircon and monazite evaporation of radiogenic lead were performed on a Finnigan Mat 262 mass spectrometer at Géosciences Rennes-CNRS, France, following procedures described in Peucat and Kouamelan (1997) and Peucat et al. (1999). Replicate analyses of NBS $987 \mathrm{Sr}$ standard provide an average ${ }^{87} \mathrm{Sr} /{ }^{86} \mathrm{Sr}$ ratios of 0.710246 \pm 17 . Replicate analyses of the AMS Nd standard provide an average ${ }^{143} \mathrm{Nd} /{ }^{144} \mathrm{Nd}$ value of $0.5118962 \pm$ 7. $\mathrm{Nd} \mathrm{T}_{\mathrm{DM}}$ model ages are calculated using $\varepsilon_{\mathrm{Nd}}$ values of +10 and +8 for the present-day depleted mantle and ${ }^{147} \mathrm{Sm} /{ }^{144} \mathrm{Nd}=0.2137$, assuming a radiogenic linear growth for the mantle starting at $4.54 \mathrm{Ga}$. Mean ratios of ${ }^{206} \mathrm{~Pb} /{ }^{204} \mathrm{~Pb}=2759 \pm 1,{ }^{207} \mathrm{~Pb} /{ }^{206} \mathrm{~Pb}=0.07124$ \pm 1 were obtained for NBS 983 standard. Correction of common lead was done from ${ }^{206} \mathrm{~Pb} /{ }^{204} \mathrm{~Pb}$ ratios measured using the Stacey and Kramer (1975) model. All ages are calculated using the decay constants and isotopes abundances listed by Steiger and Jäger (1977).

New dating has been performed to constrain the time of diapiric emplacement of the Brejões dome. $\mathrm{Sr}$ and $\mathrm{Nd}$ whole rock dating ${ }^{207} \mathrm{~Pb} /{ }^{206} \mathrm{~Pb}$ zircon and monazite evaporation ages were performed on: (i) a granitic rock interpreted to represent partial melt produced from supracrustal protoliths; (ii) the $\mathrm{CH} 6$ charnockite located in the internal part of the dome and, (iii) the HG heterogeneous granulites surrounding domes (Fig. 4). The aim of this work is to ascertain the ages of protoliths, magmatism and metamorphism related to the doming event.

The garnet-cordierite-bearing charnockite BJ-137 is a foliation-free leucocratic rock intruding into the supracrustal rim surrounding of the Brejões dome (Fig. 4). This rock is a "S type granite" with plutonic mineralogy, interpreted as resulting from supracrustal partial melting during the metamorphic climax contemporaneous with dome emplacement (Barbosa, 1990). A $2.97 \mathrm{Ga} \mathrm{T}_{\mathrm{DM}} \mathrm{Nd}$ age has been obtained, $\varepsilon_{\mathrm{Nd}}$ at $2.1 \mathrm{Ga}$ is -10 , with an initial ${ }^{87} \mathrm{Sr} /{ }^{86} \mathrm{Sr}$ of 0.712 (Table 2). Zircons grains are complex and exhibit round cores probably inherited from Archaean protoliths. Some grains are devoid of internal structures. One of these grains provided ${ }^{207} \mathrm{~Pb} /{ }^{206} \mathrm{~Pb}$ age at ca $2.0-2.1 \mathrm{Ga}$ (Table 3), indicating Palaeoproterozoic recrystallisation. This is confirmed by a ${ }^{207} \mathrm{~Pb} /{ }^{206} \mathrm{~Pb}$ age of 2052 $\pm 2 \mathrm{Ma}$ obtained by thermal evaporation on monazite from the same sample (Table 3). It is interpreted as a cooling age, after partial melting of supracrustals, under the closure temperature of the U-Pb system in monazite (ca $750{ }^{\circ} \mathrm{C}$ or above, Cocherie et al., 1998).

Samples BJ-188, PJ-07-B, TB-19-B are heterogeneous granulites (Fig. 4) from around the Brejões and Cravolândia domes. PJ-07-A is a granitic mobilizate that crosscuts the PJ-07-B charnockite. All $\mathrm{T}_{\mathrm{DMNd}}$ model ages range between 2.90 and $3.25 \mathrm{Ga}$ (Table 2). Zircon from granulites BJ-188 and TB-19-B are euhedral with magmatic zoning (S18 to S23 types of Pupin, 1980). Fine clear unzoned tips may correspond to metamorphic recrystallisations. ${ }^{207} \mathrm{~Pb} /{ }^{206} \mathrm{~Pb}$ ages ranging from 2.45 to $2.56 \mathrm{Ga}$ (Table 4) are probably mixed ages intermediate between magmatic and metamorphic ages. They are interpreted as minimum ages for the magmatic protolith and appear to be in reasonable agreement with the $2.7 \mathrm{Ga} \mathrm{Rb}-\mathrm{Sr}$ age (Wilson, 1987). Monazite ages are younger and similar in both PJ-07-B and PJ-07-A: $2047 \pm 2$ and $2044 \pm 1 \mathrm{Ma}$, respectively. A weighted average age of $2045 \pm 2.5 \mathrm{Ma}$ has been calculated for monazite from heterogeneous granulites. These data suggest that the heterogeneous granulites: (i) are derived from Archaean protoliths (3.2-2.9 Ga $\mathrm{Nd}$ model ages), (ii) were reworked during a magmatic stage which is not well constrained by zircon 
Table 4

Representative chemical analyses of $\mathrm{CH} 1$ and $\mathrm{CH} 2$ charnoenderbite-charnockites and $\mathrm{CH} 6$ charnockites

\begin{tabular}{|c|c|c|c|c|c|c|c|c|c|c|c|c|c|c|c|c|c|c|c|c|}
\hline & \multicolumn{6}{|c|}{ CH1 charnoenderbites-charnockites } & \multicolumn{6}{|c|}{$\mathrm{CH} 2$ charnoenderbites-charnockites } & \multicolumn{5}{|c|}{ CH6 charnockttes } & \multirow{2}{*}{$\begin{array}{l}\text { Average CH1 } \\
\text { (27 samples) }\end{array}$} & \multirow{2}{*}{$\begin{array}{l}\text { Average } \mathrm{CH} 2 \\
\text { (42 samples) }\end{array}$} & \multirow{2}{*}{$\begin{array}{l}\text { Average } \mathrm{CH} 6 \\
\text { (12 samples) }\end{array}$} \\
\hline & JA $11 \mathrm{~A}$ & BJ $247 \mathrm{~A}$ & JA $38 \mathrm{~A}$ & $\mathrm{JF} 61 \mathrm{~A}$ & JA 19 A & JA 49 A & $3 \mathrm{~B}$ & IJ 17 & JA $44 \mathrm{~A}$ & JD 15 & IJ 28 & Zl 10 & TA 17 & IJ 20 & TB 37 & IJ 22 & IJ $07 \mathrm{~A}$ & & & \\
\hline$\overline{\mathrm{SiO}_{2}}$ & 68.31 & 70.12 & 72.17 & 73.57 & 74.40 & 74.26 & 65.69 & 67.87 & 68.90 & 69.37 & 71.31 & 73.05 & 70.28 & 71.60 & 72.00 & 72.63 & 76.34 & 72.25 & 69.34 & 72.74 \\
\hline $\mathrm{TiO}_{2}$ & 0.46 & 0.41 & 0.32 & 0.25 & 0.17 & 0.11 & 1.23 & 1.00 & 0.79 & 0.70 & 0.43 & 0.30 & 0.62 & 0.49 & 0.54 & 0.48 & 0.28 & 0.38 & 0.78 & 0.46 \\
\hline $\mathrm{Al}_{2} \mathrm{O}_{3}$ & 15.26 & 15.46 & 14.4 & 13.80 & 13.70 & 1357 & 12.87 & 13.12 & 13.50 & 13.80 & 13.40 & 13.13 & 12.73 & 13.00 & 12.50 & 12.60 & 11.60 & 1356 & 13.12 & 1225 \\
\hline $\mathrm{Fe}_{2} \mathrm{O}_{3}$ & 4.91 & 3.49 & 2.00 & 1.89 & 1.09 & 0.98 & 7.54 & 6.99 & 5.10 & 5.55 & 4.66 & 3.72 & 5.40 & 4.66 & 5.10 & 4.44 & 2.71 & 2.96 & 6.02 & 4.60 \\
\hline $\mathrm{MnO}$ & 0.04 & 0.06 & 0.03 & 0.03 & 0.32 & 0.01 & 0.48 & 0.12 & 0.25 & 0.13 & 0.17 & 0.10 & 0.09 & 0.10 & 0.13 & 0.11 & 0.10 & 0.04 & 0.09 & 0.07 \\
\hline $\mathrm{MgO}$ & 0.81 & 0.95 & 0.66 & 0.60 & 0.27 & 0.34 & 1.07 & 0.89 & 0.96 & 0.76 & 0.35 & 0.43 & 0.52 & 0.38 & 0.33 & 0.37 & 0.41 & 0.48 & 0.71 & 0.36 \\
\hline $\mathrm{CaO}$ & 2.92 & 2.95 & 1.50 & 2.00 & 1.50 & 1.20 & 4.20 & 2.90 & 2.90 & 2.40 & 1.40 & 1.30 & 1.80 & 1.40 & 1.20 & 1.30 & 0.45 & 1.90 & 2.50 & 1.33 \\
\hline $\mathrm{Na}_{2} \mathrm{O}$ & 4.14 & 3.41 & 3.00 & 4.10 & 3.20 & 3.52 & 3.17 & 2.60 & 3.40 & 3.10 & 2.40 & 2.60 & 2.71 & 2.40 & 2.40 & 2.40 & 2.50 & 3.52 & 3.03 & 2.58 \\
\hline $\mathrm{K}_{2} \mathrm{O}$ & 3.13 & 3.00 & 5.80 & 3.70 & 5.10 & 5.53 & 3.27 & 4.41 & 3.80 & 4.00 & 5.80 & 5.41 & 5.81 & 5.90 & 5.70 & 5.60 & 5.60 & 4.41 & 4.18 & 5.51 \\
\hline $\mathrm{P}_{2} \mathrm{O}_{5}$ & 0.06 & 0.15 & 0.12 & 0.06 & 0.05 & 0.08 & 0.48 & 0.32 & 0.30 & 0.19 & 0.08 & 0.06 & 0.13 & 0.07 & 0.09 & 0.07 & 0.09 & 0.10 & 0.24 & 0.10 \\
\hline Total & 100.04 & 100.00 & 100.00 & 100.00 & 99.80 & 100.00 & 100.00 & 100.12 & 99.90 & 100.00 & 100.00 & 100.00 & 100.00 & 100.00 & 100.00 & 100.00 & 100.08 & 100.00 & 100.00 & 100.00 \\
\hline $\mathrm{Rb}$ & 58 & 182 & 170 & 95 & 91 & 210 & 92 & 117 & 94 & 139 & 208 & 111 & 264 & 310 & 306 & 222 & 275 & 136 & 111 & 285 \\
\hline $\mathrm{Ba}$ & 1470 & 1141 & - & 720 & 1090 & 1520 & 1448 & 1080 & 1400 & 1005 & 730 & 770 & 787 & 570 & 634 & 672 & 356 & 1033 & 1144 & 660 \\
\hline $\mathrm{Sr}$ & 680 & 620 & 320 & 240 & 270 & 440 & 287 & 248 & 280 & 226 & 77 & 110 & 97 & 79 & 84 & 76 & 49 & 286 & 217 & 80 \\
\hline $\mathrm{Zr}$ & 160 & 112 & 290 & 240 & 190 & 93 & 400 & 439 & 470 & 357 & 470 & 346 & 585 & 467 & 610 & 541 & 388 & 748 & 408 & 516 \\
\hline $\mathrm{Y}$ & 10 & 31 & 18 & 19 & 10 & 12 & - & 62 & 48 & 51 & 68 & 48 & 38 & 91 & 98 & 94 & 126 & 17 & 47 & 79 \\
\hline $\mathrm{Nb}$ & - & 23 & - & 20 & - & - & - & - & - & 24 & 29 & - & - & 43 & 26 & 33 & - & - & - & - \\
\hline $\mathrm{La}$ & 64.98 & - & - & 27.25 & 45.42 & 17.24 & 75.32 & 72.56 & 42.08 & 74.52 & 70.46 & 74.15 & 87.71 & 108.40 & 90.96 & 118.20 & 116.70 & 38.72 & 73.85 & 104 \\
\hline $\mathrm{Ce}$ & 123.70 & - & - & 42.50 & 91.87 & 34.63 & 146.71 & 166 & 95.10 & 163.20 & 155.20 & 155.70 & 196.70 & 230.00 & 190.10 & 181.20 & 247.50 & 73.20 & 157.26 & 209 \\
\hline $\mathrm{Nd}$ & 47.44 & - & - & 15.28 & 30.50 & 12.05 & 68.07 & 70.11 & 44.10 & $60 / 47$ & 54.63 & 57.93 & 74.52 & 87.47 & 67.35 & 111.80 & 91.40 & 2651 & 64 & 86 \\
\hline $\mathrm{Sm}$ & 6.83 & - & - & 2.24 & 5.23 & 2.15 & 12.82 & 9.43 & 8.65 & 11.56 & 10.59 & 9.24 & 13.35 & 12.50 & 12.85 & 18.04 & 13.50 & 4.13 & 12 & 14 \\
\hline Eu & 1.27 & - & - & 0.48 & 0.93 & 0.65 & 2.92 & 2.18 & 2.00 & 2.00 & 1.34 & 1.28 & 1.86 & 1.68 & 1.27 & 1.66 & 1.02 & 0.83 & 1.99 & 1.50 \\
\hline $\mathrm{Gd}$ & 4.01 & - & - & 1.44 & 2.99 & 1.32 & 9.83 & 8.85 & 6.85 & 7.61 & 6.89 & 5.99 & 8.80 & 11.37 & 8.55 & 12.66 & 10.77 & 2.84 & 8.14 & 10.40 \\
\hline Dy & 1.97 & - & - & 1.13 & 1.10 & 0.68 & 7.06 & 8.46 & 6.05 & 7.97 & 6.55 & 6.57 & 6.41 & 1152 & 7.46 & 14.57 & 12.37 & 1.22 & 8.03 & 10.80 \\
\hline Er & 0.80 & - & - & 0.47 & 0.47 & 0.34 & 3.22 & 4.03 & 3.22 & 4.13 & 3.09 & 3.30 & 3.99 & 5.54 & 3.31 & - & 6.36 & 0.52 & 4.48 & 4.80 \\
\hline $\mathrm{Yb}$ & 0.55 & - & - & 0.57 & 0.22 & 0.28 & 2.87 & 2.83 & 2.59 & 3.01 & 2.29 & 2.60 & 2.72 & 3.86 & 1.88 & - & 4.79 & 0.39 & 3.02 & 3.96 \\
\hline $\mathrm{Lu}$ & 0.08 & - & - & 0.09 & 0.11 & 0.10 & 0.40 & 0.35 & 0.39 & 0.37 & 0.28 & 0.29 & 0.32 & 0.46 & 0.19 & 0.80 & 0.53 & 0.09 & 0.37 & 0.92 \\
\hline Co & - & - & - & - & - & - & 35 & 23 & - & 10 & 21 & 10 & - & 24 & - & 21 & 13 & 3 & 17 & 19 \\
\hline $\mathrm{V}$ & - & - & - & - & - & - & 53 & 48 & - & 31 & 10 & 10 & - & 30 & - & 19 & 10 & 11 & 51 & 20 \\
\hline $\mathrm{Ni}$ & - & 20 & - & 15 & - & - & 12 & 48 & - & 12 & 27 & 18 & - & 43 & - & 52 & 41 & 13 & 17 & 45 \\
\hline $\mathrm{Cr}$ & - & 33 & - & 8 & - & - & 17 & 93 & - & 43 & 67 & 25 & - & 73 & - & 76 & 62 & 19 & 31 & 70 \\
\hline$\underline{\mathrm{Cu}}$ & - & 10 & - & - & - & - & 26 & 26 & - & 11 & 15 & 18 & - & 57 & - & 26 & 27 & 12 & 20 & 37 \\
\hline
\end{tabular}


evaporation ages $(>2.56 \mathrm{Ga})$ but probably close to $2.7 \mathrm{Ga}$ and (iii) metamorphosed in the granulite facies during the Palaeoproterozoic, cooling temperature of ca $750{ }^{\circ} \mathrm{C}$ being reached at about $2.05 \mathrm{Ga}$.

Among the CH6 charnockite sample IJ-22 is from the Brejões dome and TB-19-A from the southern Cravolândia dome (Figs. 3 and 4). The $\mathrm{T}_{\mathrm{DM}} \mathrm{Nd}$ model age of IJ 22 is ca $3.2 \mathrm{Ga}$ (Table 2), similar to that obtained by Wilson (1987). This suggests that the CH6 charnockites also derived from old Archaean protolith, the high ${ }^{87} \mathrm{Sr} /{ }^{86} \mathrm{Sr}(0.773$, Table 2$)$ at $2.1 \mathrm{Ga}$ supports this interpretation. Zircon grains from IJ-22 and TB-19A are euhedral to subhedral, zoned, with clear overgrowths. The ${ }^{207} \mathrm{~Pb} /{ }^{206} \mathrm{~Pb}$ ages range from 2.20 to $2.55 \mathrm{Ga}$ for IJ-22 and 2.03 to $2.25 \mathrm{Ga}$ for TB-19-A. This wide range of ages probably corresponds to the mixing of magmatic zircon older than $2.55 \mathrm{Ga}$ with metamorphic overgrowths at ca $2 \mathrm{Ga}$. Two runs on monazite TB-19-A yielded a mean age of $2026 \pm 1 \mathrm{Ma}$, similar to the youngest zircon age but slightly younger than monazite ages from the northern Brejões dome. As observed for the heterogeneous granulites, the $\mathrm{CH} 6$ data suggest recycling of ca 3.0-3.2 Ga old Archean rocks during a Paleoproterozoic high-grade event. $\mathrm{Nd}$ model ages previously obtained for $\mathrm{CH} 1$ and $\mathrm{CH} 2$ are also in the same Archean range (Table 2). $\mathrm{CH} 1, \mathrm{CH} 2$ and $\mathrm{HG}$ exhibit $\varepsilon_{\mathrm{Nd}}$ values at $2.1 \mathrm{Ga}$ which are in the range of those determined for the CH6. The latter would probably result from partial melting of such granulitic gneisses as observed in the vicinity of the domes.

\section{Analytical methods and major and trace element geochemistry}

The geochemical investigation was performed on the magmatic rocks in order to constrain their petrogenesis. Samples $27 \mathrm{CH} 1,41 \mathrm{CH} 2$ and $12 \mathrm{CH} 6$ were analysed for major and trace elements. Table 4 shows six analyses representative of these different groups of charnockites. The analysis was conducted at the Lakefield GEOSOL_Geologia e Sondagem Ltda Laboratories using X-ray Fluorescence, ICP-MS and atomic absorption spectrometry. With XRF it was possible to conduct quantitative sample analysis for most major and trace elements. ICP-MS enabled determination of REE, with concentrations around 10 times of chon- drite. In the case of the atomic absorption spectrometry, a complementary technique to the ICP-MS and the $\mathrm{X}$-ray fluorescence, we have the facility to determine isolated elements such as $\mathrm{Na}_{2} \mathrm{O}$ and $\mathrm{K}_{2} \mathrm{O}$.

Whereas $\mathrm{CH} 1$ and $\mathrm{CH} 2$ have $\mathrm{SiO}_{2}$ ranging from 65 to $74 \% \mathrm{SiO}_{2}, \mathrm{CH} 6$ samples are all $\mathrm{SiO}_{2}$-rich (70-77\%). $\mathrm{CH} 1$ and $\mathrm{CH} 2$ differ in $\mathrm{Al}_{2} \mathrm{O}_{3}(13.96 \%$ and $13.12 \%$, respectively) and mainly in $\left(\mathrm{Fe}_{2} \mathrm{O}_{3}+\right.$ $\left.\mathrm{MgO}+\mathrm{TiO}_{2}\right)(3.82 \%$ and $7.51 \%$, respectively), $\mathrm{CH} 6$ being $\mathrm{Al}_{2} \mathrm{O}_{3}$ poorer $\left(\mathrm{Al}_{2} \mathrm{O}_{3}: 12 \%\right.$ ) (Table 4$)$. In $\mathrm{Q}-\mathrm{A}-\mathrm{P}$ (Fig. 5; Streckeisen, 1975) and An-Ab-Or (Fig. 6; O'Connor, 1965) normative triangles, both $\mathrm{CH} 1$ and $\mathrm{CH} 2$ display differentiation trends from granodiorite toward granite domains, whereas $\mathrm{CH} 6$ does not define real trends and is restricted to the granite field. In the AFM diagram (Fig. 7; Irvine and Baragar, 1971), except CH2, CH6, all samples plot in the calcalkaline/tholeiitic transition field, systematically near the AF sideline, lacking the less differentiated terms of typical calc-alkaline suites. This interpretation is corroborated by the $\mathrm{K}-\mathrm{Na}-\mathrm{Ca}$ triangle (Fig. 8), where data plot along an calc-alkaline (CA) trend, showing no affinity at all with trondhjemitic suites. In Fig. 8, the TDH field represents the composition of typical Archean TTG (Martin, 1994), thus it clearly appears that Brejões magmatic rocks do not belong to Archaean TTG suites, but rather possess modern calc-alkaline magma characteristics.

Harker diagrams (Fig. 9) allow separation of the three rock groups. Except for $\mathrm{K}_{2} \mathrm{O}$, in the three units (CH1, CH2, CH6) all elements are negatively correlated with $\mathrm{SiO}_{2}$. In $\mathrm{CH} 1$ and $\mathrm{CH} 2, \mathrm{~K}_{2} \mathrm{O}$ is positively correlated with $\mathrm{SiO}_{2}$, whereas in $\mathrm{CH} 6$, these two elements are slightly anticorrelated. In these diagrams, $\mathrm{TiO}_{2}$ is lower in $\mathrm{CH} 1$ than in $\mathrm{CH} 2$ which are therefore referred to as low-Ti, respectively (Fornari and Barbosa, 1994). Plotted in the same diagrams, trace elements generally show scatter (Fig. 10). However, instead of the expected scattering their content in rock decreases as $\mathrm{SiO}_{2}$ increases thus demonstrating their compatible behaviour. Similarly to $\mathrm{K}_{2} \mathrm{O}, \mathrm{Rb}$ is the only trace element that behaves as incompatible. As $\mathrm{Sr}$ and $\mathrm{Rb}$ respectively appear as the most compatible and incompatible elements, they were selected to try to discriminate between the three series.

In the normalised incompatible elements spider diagrams (Fig. 11) and chondrite-normalised REE patterns (Fig. 12), the three groups show distinct characteristics. 


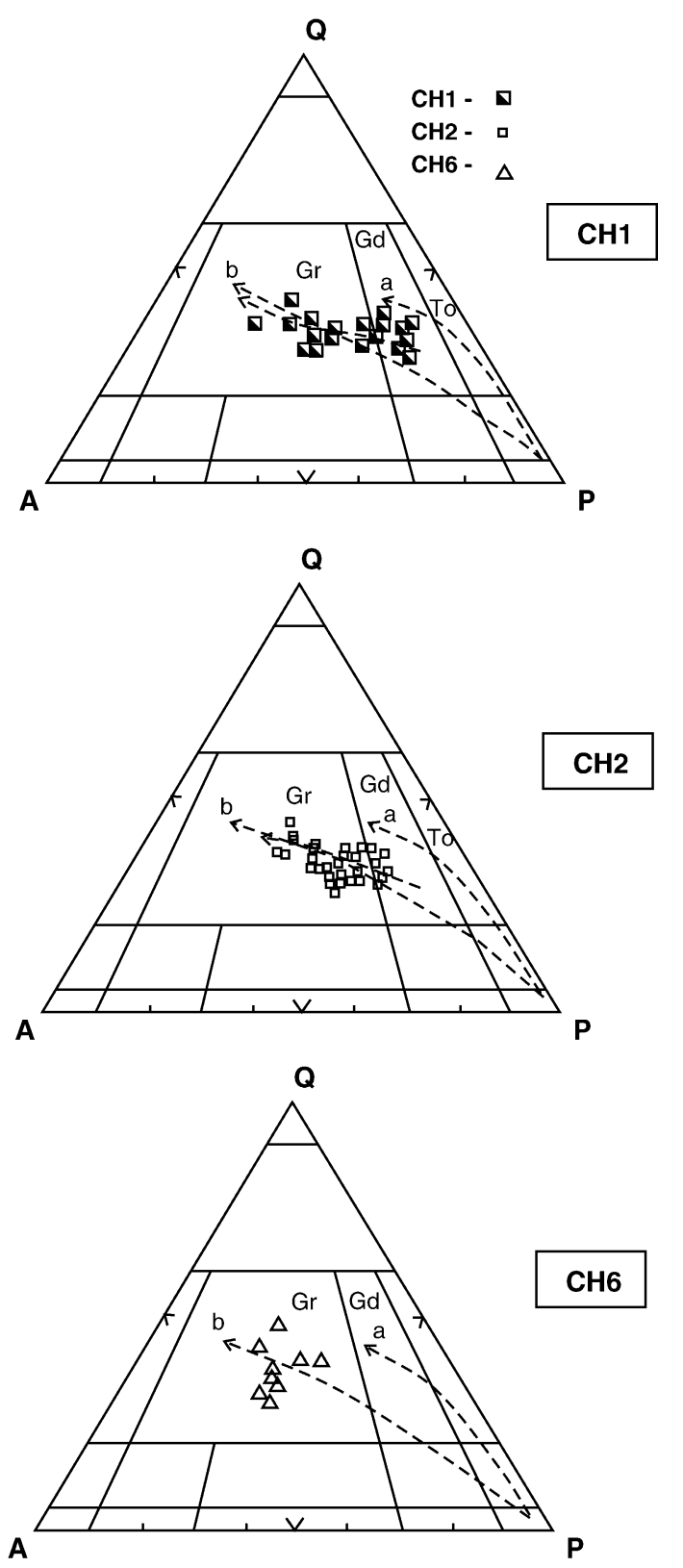

Fig. 5. Modal normative Q-A-P triangle (Streckeisen, 1975). To: tonalite/enderbite; Gd: granodiorite/charnoenderbite; Gr: granite/charnockite. Dashed lines are from Lameyre and Bowden (1982): (a) low $\mathrm{K}$ calc k-alkaline; (b) intermediate $\mathrm{K}$ calk-alkaline.

The Laje CH1 is light REE (LREE)-rich (LaN: 60-200) and heavy REE (HREE)-poor ( $\left.\mathrm{Yb}_{\mathrm{N}}: 1-2.5\right)$, resulting in high $(\mathrm{La} / \mathrm{Yb})_{\mathrm{N}}(\sim 64)$ without Eu anomaly (Fig. 12). In spider diagrams (Fig. 11), all patterns are
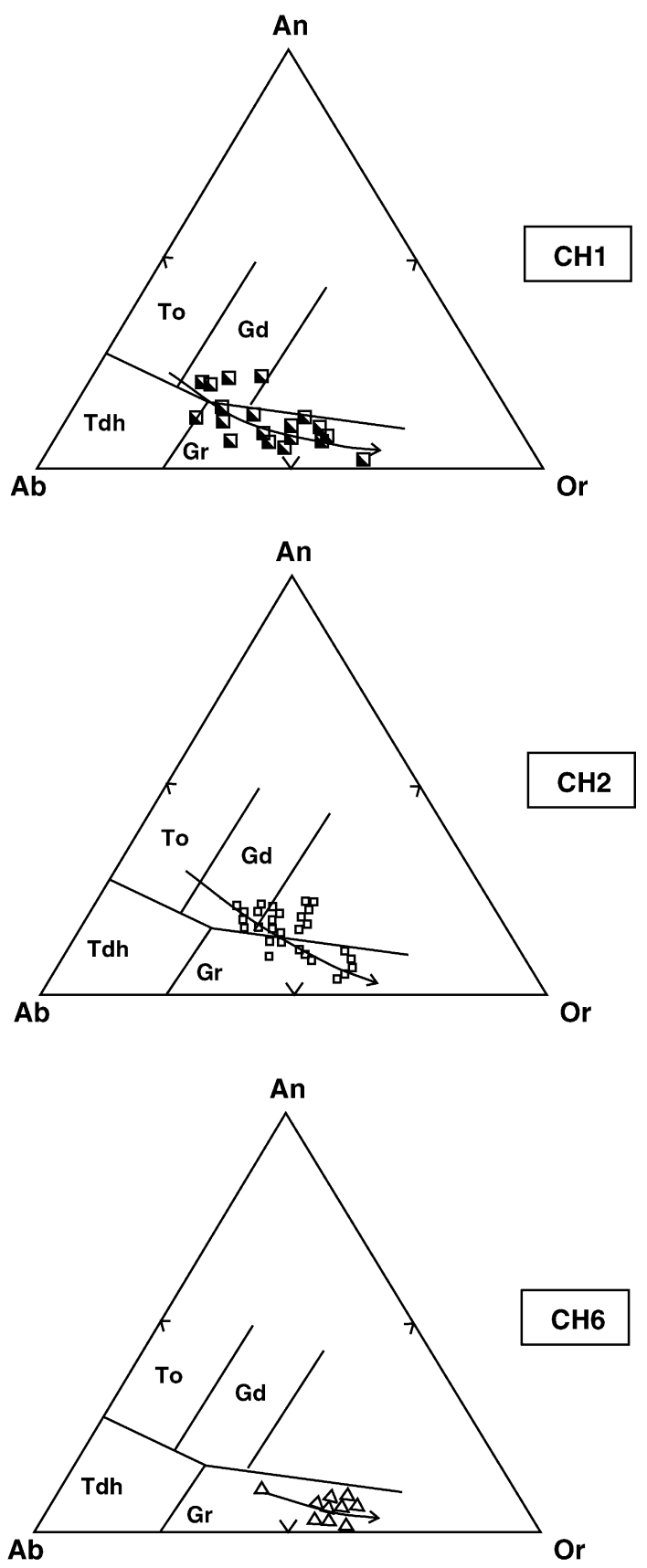

Fig. 6. Normative An-Ab-Or triangle (O'Connor, 1965). Fields are from Barker (1987). To: tonalite/enderbite; Gd: granodiorite/charnoenderbite; Gr: granite/charnockite; Tdh: trondhjemite. 

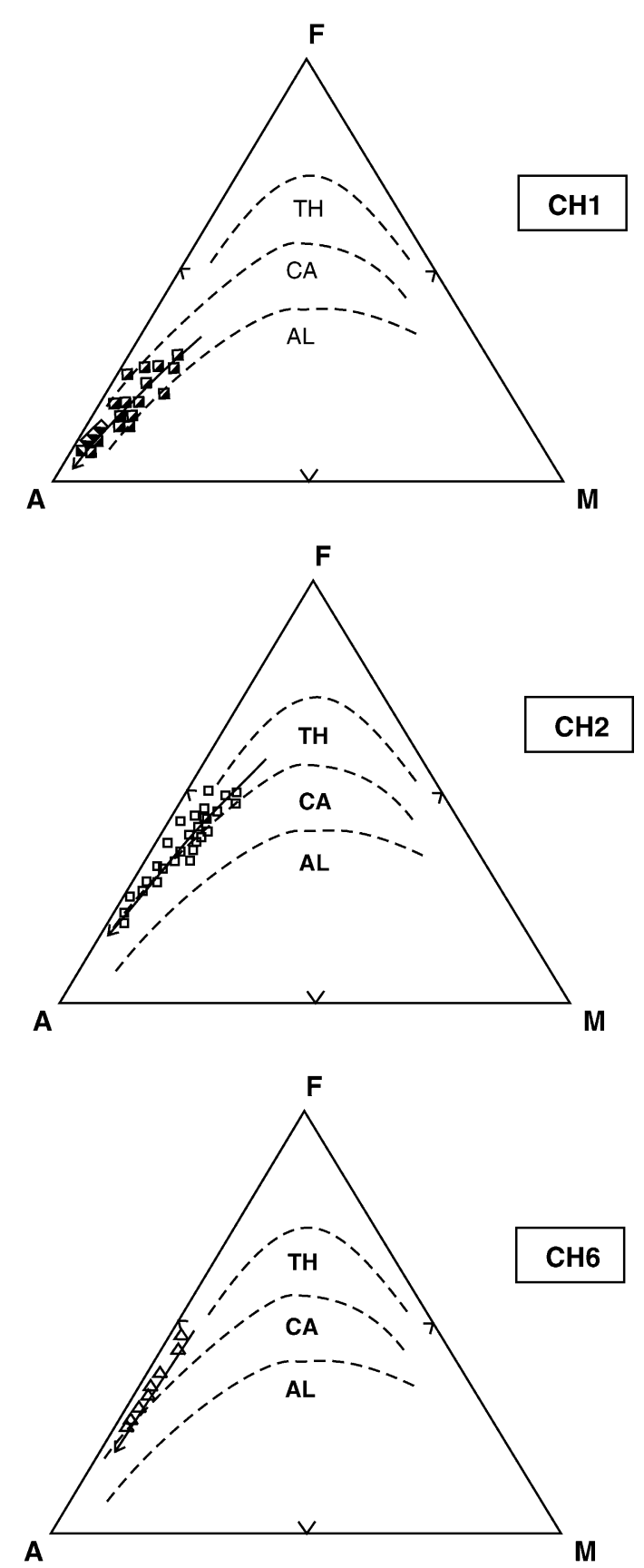

Fig. 7. A-F-M triangle (Irvine and Baragar, 1971) showing the character of the three groups of rocks. TH: tholeiitic; CA: calk-alkaline; AL: alkaline. similar showing the same enrichment in LILE $(\times 100)$; they display a negative anomaly only for Ti.

The Mutuipe $\mathrm{CH} 2$ is REE-richer $\left(\mathrm{La}_{\mathrm{N}}\right.$ : 230; $\mathrm{Yb}_{\mathrm{N}}$ : $\left.15 ;(\mathrm{La} / \mathrm{Yb})_{\mathrm{N}}: 17\right)$, with a slight but systematic negative Eu anomaly (Fig. 12). As in CH1, LILE are about 100 times enriched, but show significant $\mathrm{Nb}, \mathrm{Sr}$ and Ti negative anomalies (Fig. 11). In addition even if negative $\mathrm{Ti}$ anomalies exist, $\mathrm{CH} 2$ is Ti-richer than $\mathrm{CH} 1(0.78 \%$ and $0.38 \%$, respectively).

The Brejões CH6 dome REE patterns display an important negative Eu anomaly, as well as high $\mathrm{La}_{\mathrm{N}}$ $(\sim 330), \mathrm{Yb}_{\mathrm{N}}(\sim 19)$ (Fig. 12) and low $(\mathrm{La} / \mathrm{Yb})_{\mathrm{N}}(17)$. As for $\mathrm{CH} 2$, these rocks are LILE-rich but in addition to $\mathrm{Nb}, \mathrm{Sr}$ and Ti negative anomalies they have a significant Ba negative anomaly (Fig. 11).

\section{Mechanisms of differentiation and sources}

\subsection{1.Mechanisms of differentiation for the $\mathrm{CH} 1$ and $\mathrm{CH} 2$ granulites}

In Harker plots (Figs. 9 and 10) $\mathrm{SiO}_{2}$ has been used as an index of differentiation. $\mathrm{CH} 1$ and $\mathrm{CH} 2$ data plot as curved lines in these diagrams for major elements and where there is little scattering, display curved lines for trace elements. Unfortunately, CH6 does not draw so well-defined differentiation trends. These figures, with curved trends for trace elements preclude that trends could result from mixing processes, consequently they rather characterise magmatic processes such as fractional crystallisation or partial melting. Log[compatible element] versus Log[incompatible element] has been used to distinguish between the two mechanisms. In Fig. 10, $\mathrm{Rb}$ is positively and $\mathrm{Sr}$ negatively correlated with index of differentiation $\left(\mathrm{SiO}_{2}\right)$, thus demonstrating the compatible behaviour of $\mathrm{Sr}$ and the incompatible one of $\mathrm{Rb}$. In Fig. 13, both $\mathrm{CH} 1$ and $\mathrm{CH} 2$ show almost vertical trends characteristic of fractional crystallisation, whereas the more horizontal trend defined by $\mathrm{CH} 6$ is better accounted for by partial melting process (Martin, 1994).

Petrogenetic modelling has been undertaken. Processes were first modelled using mass balance calculations of Störmer and Nicholls (1978). Based only on major elements, this algorithm calculates both the modal and chemical compositions of the cumulate that fractionated from the magma; in addition, the degree of 


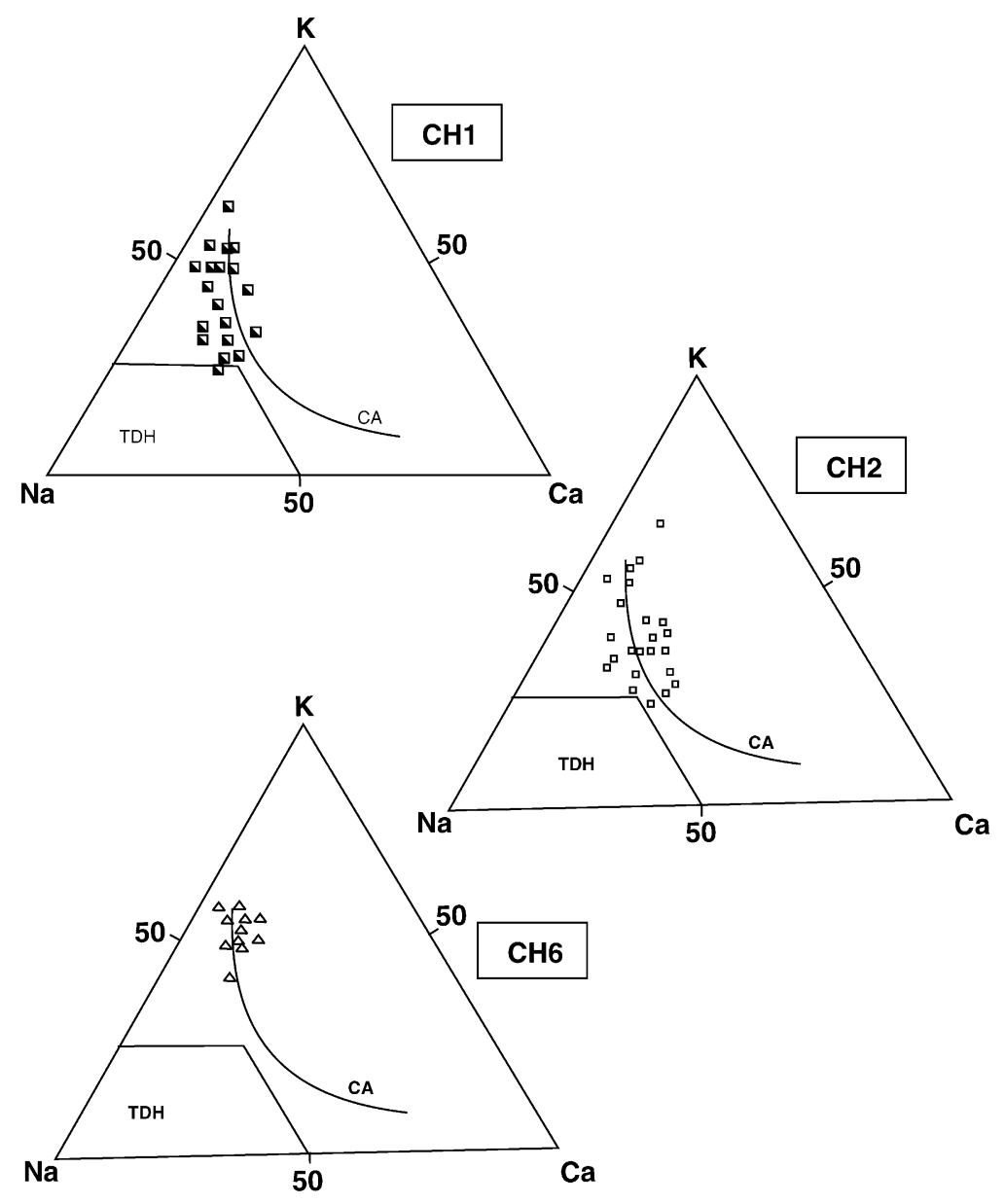

Fig. 8. K-Na-Ca triangle (Barker and Arth, 1976) showing that the three rock groups plot in the field of calk-alkaline plutonites. TDH: Archaean TTG rocks; CA: calk-alkaline rocks.

crystallisation is also obtained. A second step involves reintroducing the computed modal compositions of the cumulate and the degree of fractionation in trace element modelling. Equations are those of Rayleigh (1896) for fractional crystallisation and Shaw (1970) for partial melting.

For CH1, suite JA-11-A has been chosen as representative of the parental magma and J1-49-A as differentiated liquid. The calculated cumulate composition is: $\sim 68.0 \%$ plagioclase $\left(\mathrm{An}_{40}\right)$ and $\sim 24.2 \%$ hornblende together with magnetite $(\sim 7.6 \%)$ and ilmenite $(\sim 0.2 \%)$; the degree of crystallisation (1-F) is about $30-31 \%$ (Table 5). However, these data applied to REE modelling perfectly only when very small amounts $(0.01 \%)$ of allanite are present in the cumulate (Fig. 14).
The result of this modelling was subsequently entered into a trace element computation. When Ba is excluded, the model also perfectly accounts for other trace element distributions. It must also be noted that even with more than $68 \%$ plagioclase in the cumulate, a negative Eu anomaly is not predicted by calculation. Hornblende has low KDEu, when compared with KDSm and KDGd, thus cancelling out the effect of plagioclase fractionation. As there is a good agreement between analytical data and model, sample JA-11-A may be considered as representative of the parental magma of the $\mathrm{CH} 1$ suite (Table 6).

Major element modelling for $\mathrm{CH} 2$ leads to a cumulate made up of $47.3 \%$ plagioclase $\left(\mathrm{An}_{40}\right), 21.3 \%$ hornblende, $13.9 \%$ clinopyroxene, $7.2 \%$ magnetite, $6.9 \%$ il- 

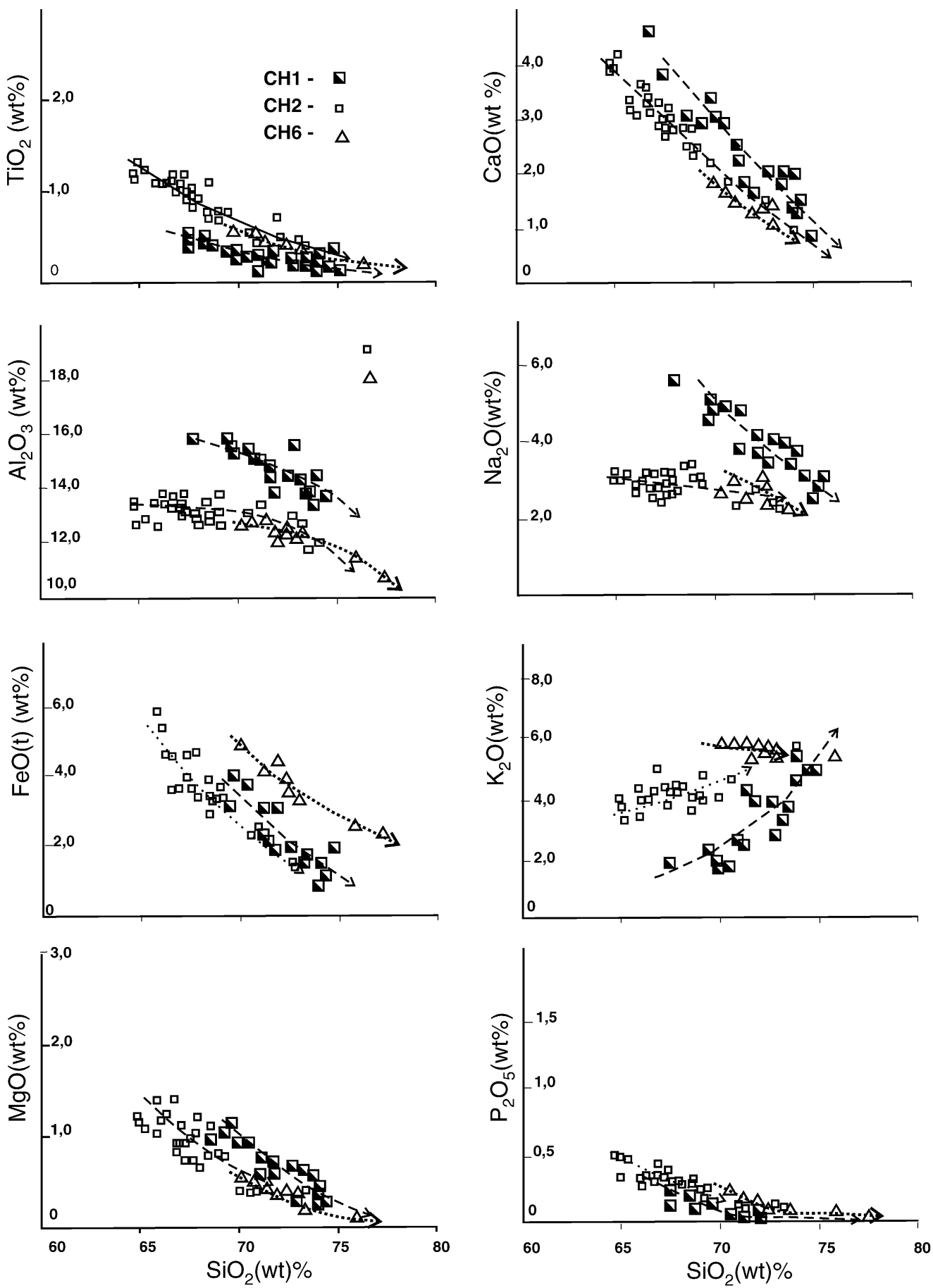

Fig. 9. Major elements in Harker diagrams for the $\mathrm{CH} 1, \mathrm{CH} 2$ and $\mathrm{CH} 6$ plutonites. 

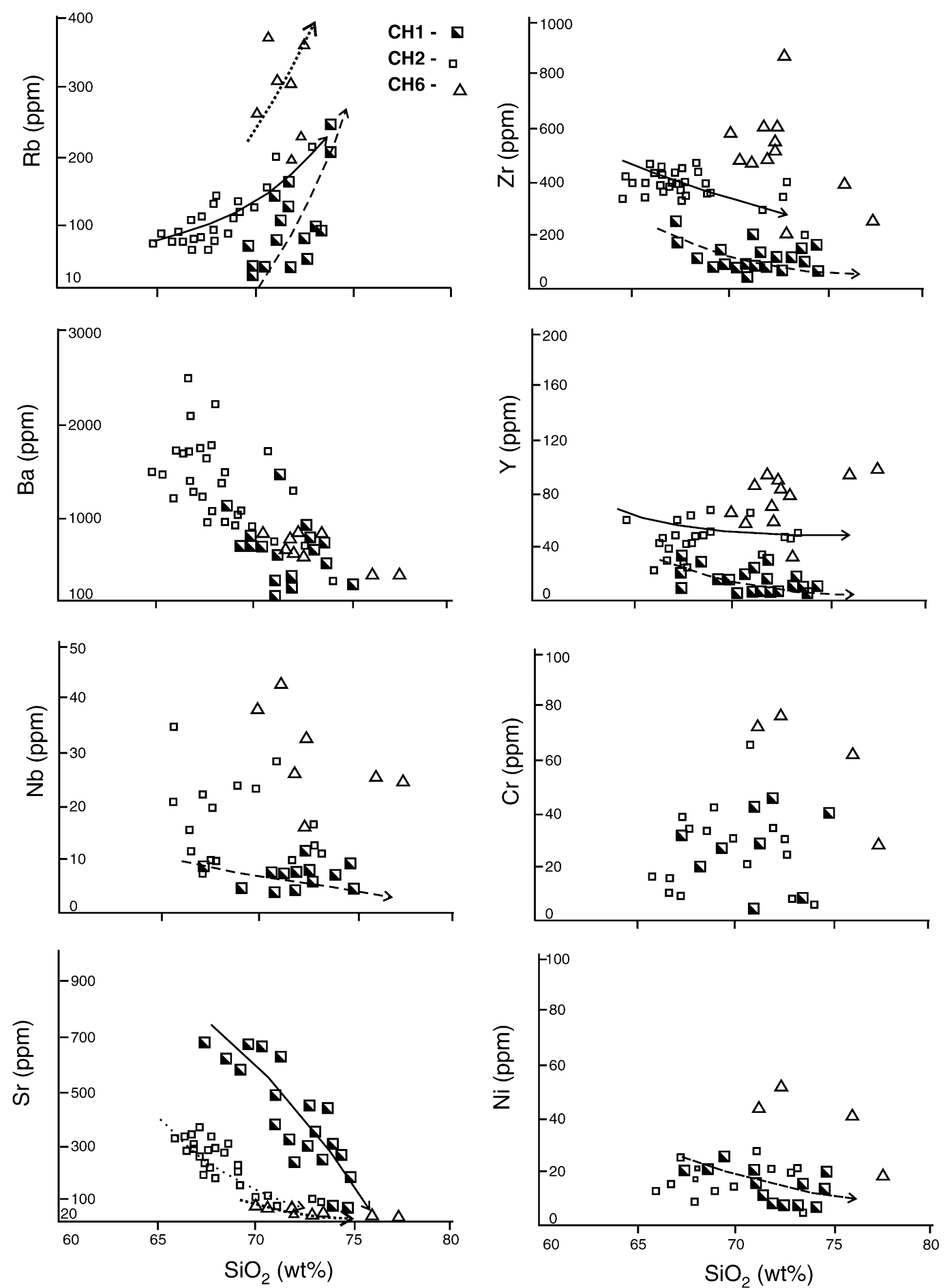

Fig. 10. Trace elements in Harker diagrams for the $\mathrm{CH} 1, \mathrm{CH} 2$ and $\mathrm{CH} 6$ plutonites. 


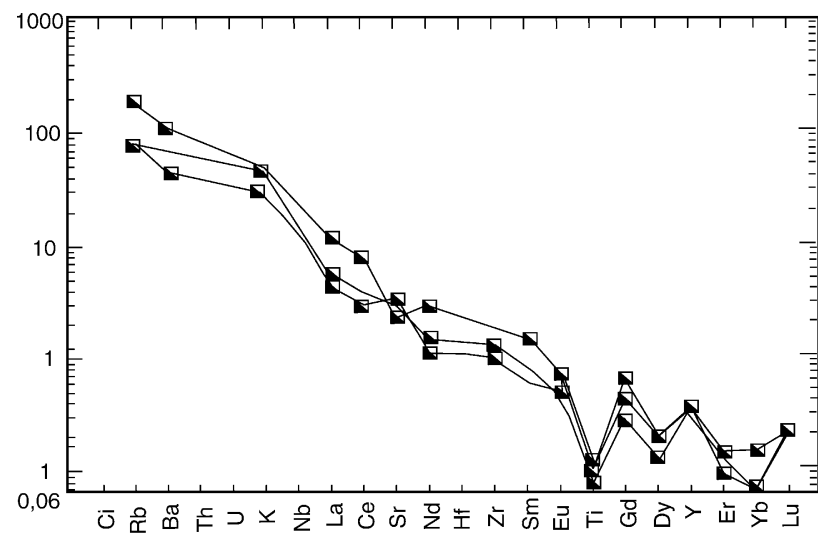

\section{$\mathrm{CH} 1$}

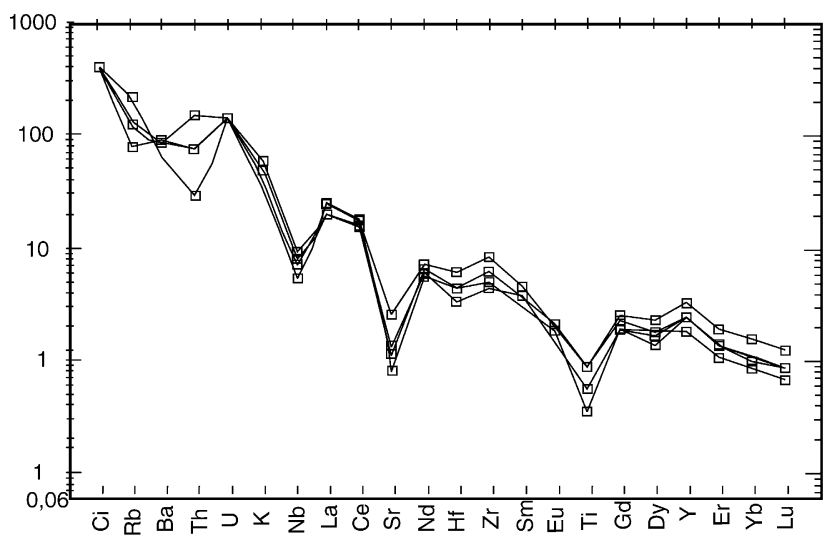

$\mathrm{CH} 2$

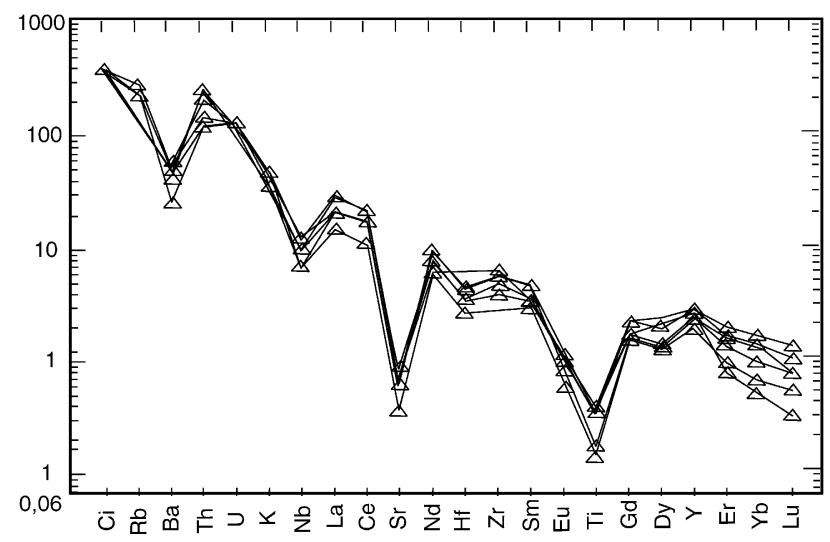

$\mathrm{CH} 6$

Fig. 11. Spider diagrams for the $\mathrm{CH} 1, \mathrm{CH} 2$ and $\mathrm{CH} 6$ plutonites.

menite, and $3.4 \%$ apatite, $((1-\mathrm{F})=20 \%)$. In this model $\mathrm{IJ}-17$ is considered as parental magma and ZI-10 as the more differentiated liquid. Fig. 15 shows that there is good agreement between calculated and real rock REE patterns. It must be noted that fractional crystallisation has only moderate effect on REE patterns. As for $\mathrm{CH} 1$, except for $\mathrm{Ba}$, all other trace element behaviour is reasonably concordant with the computed model, thus IJ17 is considered as representative of the $\mathrm{CH} 2$ parental magma (Table 2).

For both $\mathrm{CH} 1$ and $\mathrm{CH} 2$ all models implying granulitic cumulative assemblages (including orthopyrox- 


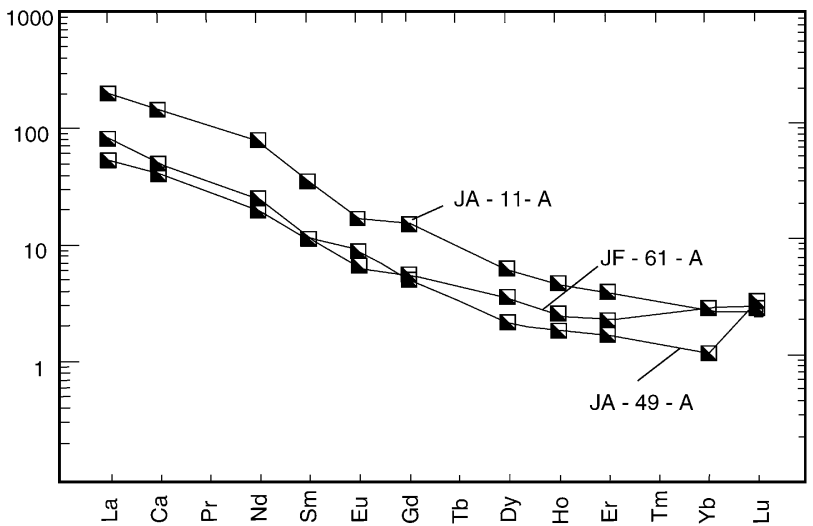

\section{$\mathrm{CH} 1$}

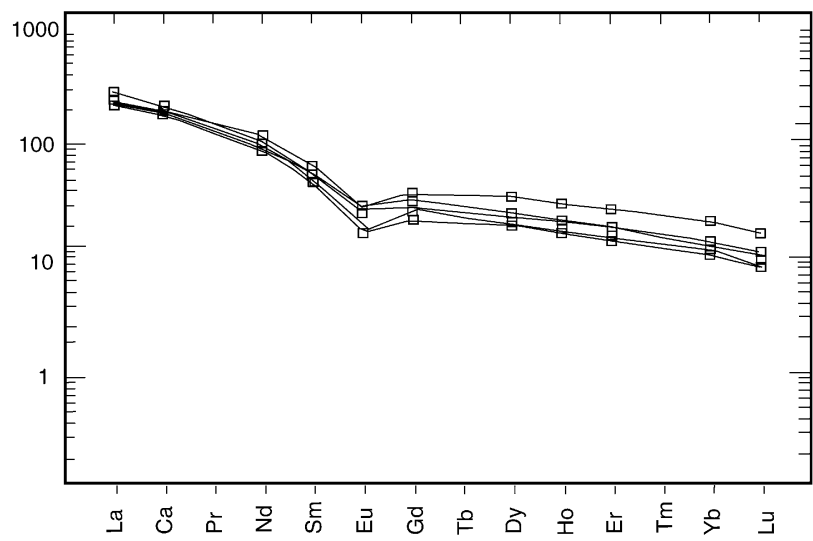

\section{$\mathrm{CH} 2$}

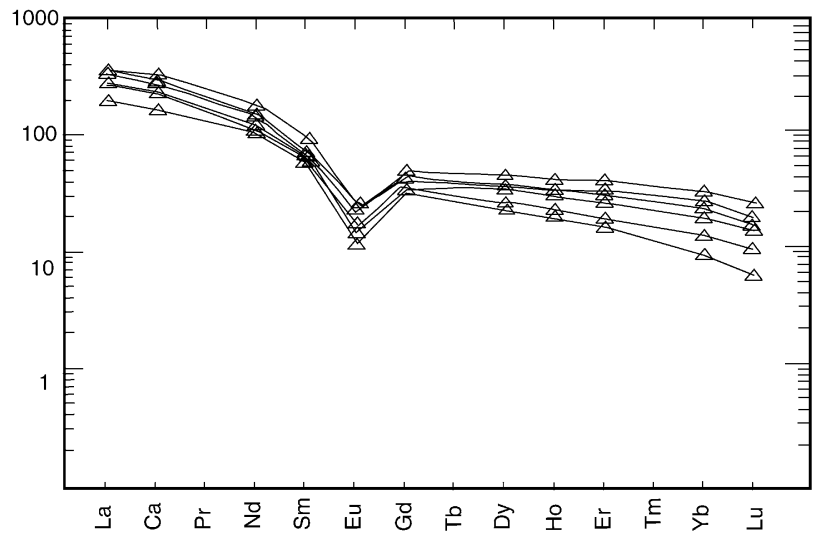

Fig. 12. Chondrite-normalised REE patterns for the $\mathrm{CH} 1, \mathrm{CH} 2$ and $\mathrm{CH} 6$ plutonites. $\mathrm{CH} 1(\mathrm{La} / \mathrm{Yb}) \mathrm{N} \cong 64 ; \mathrm{CH} 2(\mathrm{La} / \mathrm{Yb}) \mathrm{N} \cong 17 ; \mathrm{CH} 6(\mathrm{La} / \mathrm{Yb}) \mathrm{N}$ $\cong 21$. Chondritic values from Sun (1982).

ene) are not able to account for analytical data. This suggests that orthopyroxene is only a metamorphic mineral and that the magmatic precursors of both $\mathrm{CH} 1$ and $\mathrm{CH} 2$ were emplaced under amphibolite facies metamorphic conditions, and granulitic metamorphism took place after their crystallisation. This interpretation is also in agreement with the presence of orthopyroxene rims around mafic enclaves (see above). 

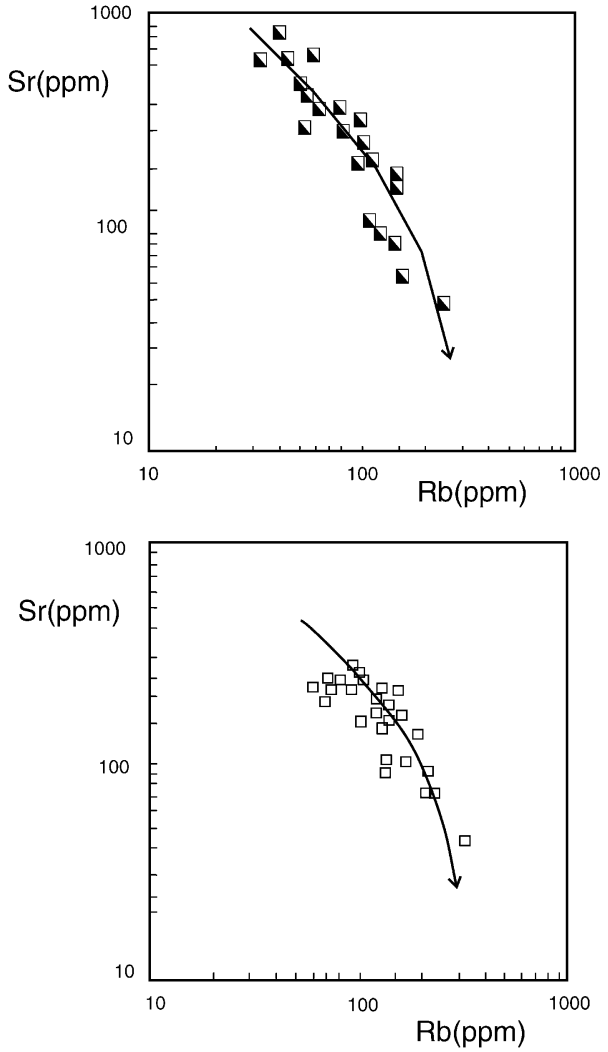

$\mathrm{CH} 2$

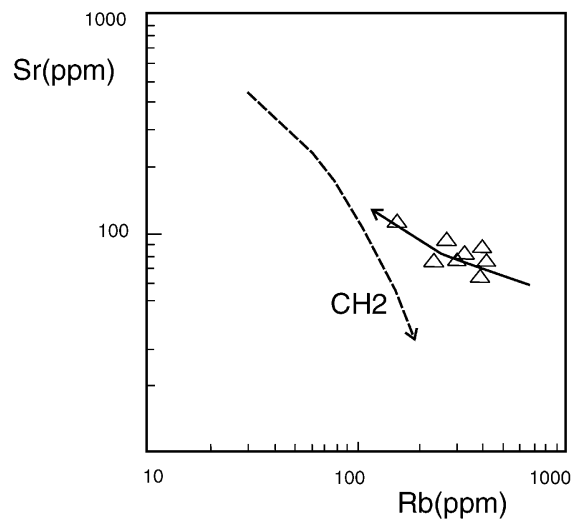

Fig. 13. $\log (\mathrm{Sr})$ incompatible vs. $\log (\mathrm{Rb})$ compatible diagram for $\mathrm{CH} 1, \mathrm{CH} 2$ and $\mathrm{CH} 6$ plutonites. $\mathrm{CH} 1$ and $\mathrm{CH} 2$ indicate fractional crystallisation trends and $\mathrm{CH} 6$, partial melting process.

\subsection{Possible sources for $\mathrm{CH} 1, \mathrm{CH} 2$ and $\mathrm{CH} 6$ granulites}

Several attempts to model $\mathrm{CH} 1$ and $\mathrm{CH} 2$ sources were unsuccessful. Thus, depleted or enriched mantle,

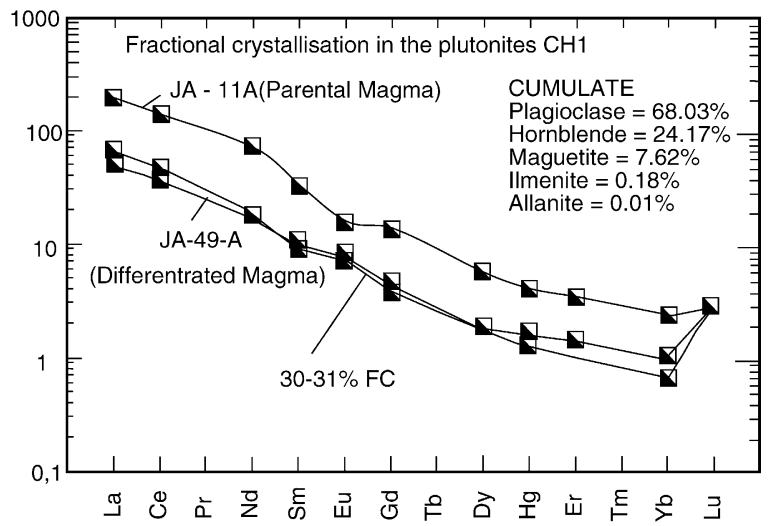

Fig. 14. REE patterns for the $\mathrm{CH} 1$ plutonites compared with the results of fractional crystallisation modelling. The composition of the cumulate and the degree of fractional crystallisation (30-31\%) are determined using major elements computation (Table 6). Chondritic values from Sun (1982).

Archaean tholeiite (Martin, 1987) and TTG (Barker and Arth, 1976) are precluded as possible protoliths. Only enriched Archaean tholeiite appears as a possible source (Condie, 1981). Partial melting ( $F=24 \%$ ) of this source can generate $\mathrm{CH} 1$ parental magma leaving a residue composed of plagioclase $\mathrm{An}_{60}(23.0 \%)$, clinopyroxene $(42.5 \%)$, garnet $(23.4 \%)$, hornblende $6.0 \%$, magnetite $(2.7 \%)$, ilmenite $(2.4 \%)$. Similarly, it is possible to produce $\mathrm{CH} 2$ by $23 \%$ melting of an enriched tholeiite with a residue made up of pla-

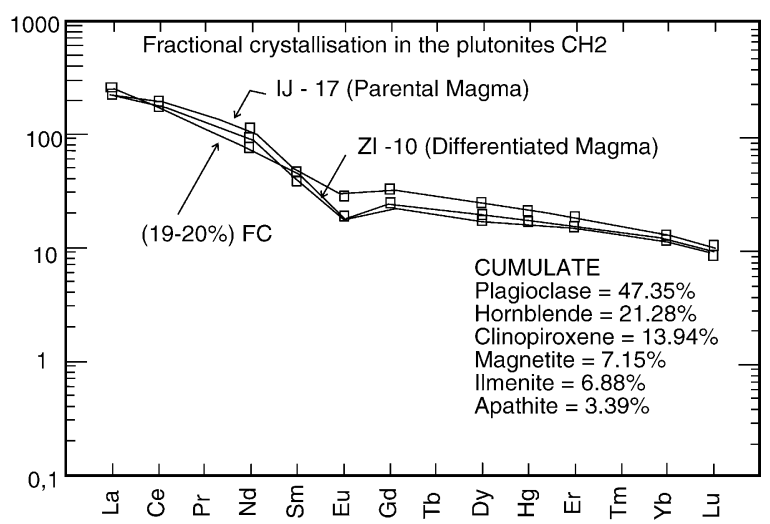

Fig. 15. REE patterns for the $\mathrm{CH} 2$ plutonites compared with the results of fractional crystallisation modelling. The composition of the cumulate and the degree of fractional crystallisation (19-20\%) are determined using major elements computation (Table 7). Chondritic values from Sun (1982). 
Table 5

Major element modelling of fractional crystallisation in the $\mathrm{CH} 1$ plutonites

\begin{tabular}{lllll}
\hline Elements & Parental magma JA-11-A & Residual liquid JA-49-A & $30-31 \%$ Fractional crystallization & Modal composition of cumulate (\%) \\
\hline $\mathrm{SiO}_{2}$ & 68.31 & 74.26 & 74.25 & Plagioclase $=68.03$ \\
$\mathrm{Al}_{2} \mathrm{O}_{3}$ & 15.26 & 13.97 & 13.79 & Hornblende $=24.17$ \\
$\mathrm{Fe}_{2} \mathrm{O}_{3}$ & 4.91 & 0.98 & 1.29 & Magnetite $=7.62$ \\
$\mathrm{MgO}$ & 0.81 & 0.34 & 0.35 & llmenite $=0.18$ \\
$\mathrm{CaO}$ & 2.92 & 1.20 & 1.66 & Allanite $=0.01$ \\
$\mathrm{NaO}_{2}$ & 4.14 & 3.52 & 3.22 & \\
$\mathrm{~K}_{2} \mathrm{O}$ & 3.13 & 5.53 & 4.71 & \\
$\mathrm{~F}_{2} \mathrm{O}_{2}$ & 0.46 & 0.11 & 0.43 & \\
$\mathrm{P}_{2} \mathrm{O}_{5}$ & 0.06 & 0.08 & 0.09 & \\
\hline
\end{tabular}

Table 6

Major element modelling of fractional crystallisation in the $\mathrm{CH} 2$ plutonites

\begin{tabular}{lllll}
\hline Elements & Parental magma IJ -17 & Residual liquid Zl-10 & Fractional crystallization 19-20\% & Modal composition of cumulate (\%) \\
\hline $\mathrm{SiO}_{2}$ & 67.87 & 73.05 & 73.35 & Plagioclase $=47.35$ \\
$\mathrm{Al}_{2} \mathrm{O}_{3}$ & 13.12 & 13.13 & 13.21 & Hornblende $=21.28$ \\
$\mathrm{Fe}_{2} \mathrm{O}_{3}$ & 6.89 & 3.72 & 3.58 & Clinopyroxene $=13.94$ \\
$\mathrm{MgO}$ & 0.89 & 0.43 & 0.36 & Magnetite $=7.15$ \\
$\mathrm{CaO}$ & 2.90 & 1.30 & 1.27 & llmenite $=6.88$ \\
$\mathrm{Na}$ & 2.60 & 2.60 & 2.43 & Apatite $=3.39$ \\
$\mathrm{~K}_{2} \mathrm{O}$ & 4.41 & 5.41 & 5.47 & \\
$\mathrm{P}_{2} \mathrm{O}_{5}$ & 1.00 & 0.30 & 0.29 & \\
& 0.32 & 0.06 & 0.03 & \\
\hline
\end{tabular}

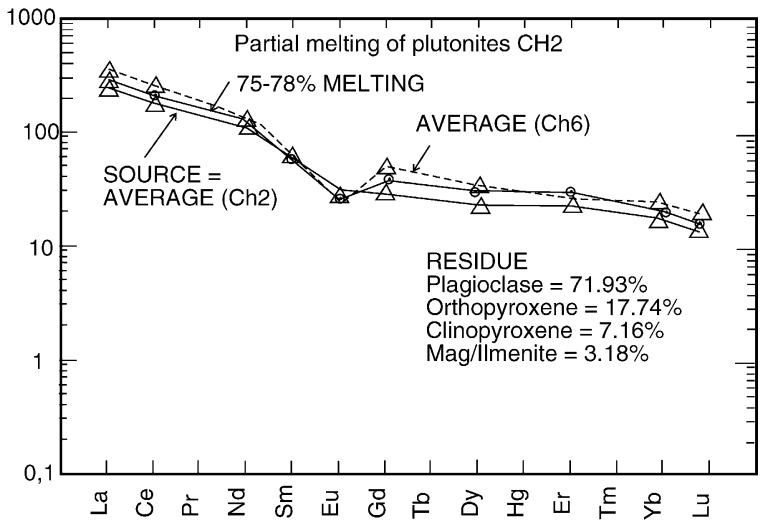

Fig. 16. REE patterns of the parental magma from CH6 plutonites, compared with the computed composition of a magma (heavy line) derived from partial melting (75-78\%) of the average $\mathrm{CH} 2$ (Table 8). Chondritic values from Sun (1982).

gioclase $\mathrm{An}_{60}(26.1 \%)$, clinopyroxene (33.7\%), hornblende $(21.9 \%)$, garnet $(14.0 \%)$, magnetite $(2.8 \%)$ and ilmenite (1.5\%).

The CH6 charnockites present in the Brejões and Santa Inês domes are believed to be the result of partial melting processes as indicated by the compatible versus incompatible elements logarithmic diagram (Fig. 13). CH6 composition can be easily obtained by modelling partial melting of older crustal rocks such as an average $\mathrm{CH} 2$ (Table 7, Fig. 16). The computed residue consists of plagioclase (72\%), orthopyroxene (18\%), clinopyroxene $(7 \%)$ and magnetite/ilmenite $(3 \%)$. This process requires a high degree of source melting $(\sim 75 \%)$. It must be noted that the calculated residue contains pyroxene assemblage, which is consistent with a genesis linked to granulitic metamorphism. All calculations trying to support the hypothesis of $\mathrm{CH} 6$ derivation through $\mathrm{CH} 1$ source melting have failed.

\section{Discussions and conclusions}

Field relationships and geochronological data suggest that the SP supracrustal units found as enclaves within the HG heterogeneous granulites are among the oldest rocks of the Jequie block, even though accurate dating is not available. The magmatic precursors of $\mathrm{HG}$ yield a zircon minimum evaporation age of about $2.56 \mathrm{Ga}$ (present work) and a $\mathrm{Rb}-\mathrm{Sr}$ age of 
Table 7

Major element modelling of $\mathrm{CH} 1$ and $\mathrm{CH} 2$ partial melting for $\mathrm{CH} 6$ production

\begin{tabular}{llllll}
\hline Elements & $\begin{array}{l}\mathrm{CH} 1 \text { average } \\
27 \text { samples }\end{array}$ & $\begin{array}{l}\mathrm{CH} 2 \text { average } \\
41 \text { samples }\end{array}$ & $\begin{array}{l}\text { Partial melt of } \\
75-78 \%(\mathrm{CH} 2)\end{array}$ & $\begin{array}{l}\mathrm{CH} \text { average } \\
12 \text { samples }\end{array}$ & $\begin{array}{l}\text { Modal composition of } \\
\text { residual melt }(\%)\end{array}$ \\
\hline $\mathrm{SiO}_{2}$ & 72.25 & 69.34 & 72.70 & 72.74 & Plagioclase $=71.93$ \\
$\mathrm{Al}_{2} \mathrm{O}_{3}$ & 13.96 & 13.12 & 12.35 & 12.25 & Orthopyroxene $=17.74 \%$ \\
$\mathrm{Fe}_{2} \mathrm{O}_{3}$ & 2.96 & 6.02 & 4.76 & 4.60 & Clinopyroxene $=7.16 \%$ \\
$\mathrm{MgO}$ & 0.48 & 0.71 & 0.35 & 0.36 & \\
$\mathrm{CaO}$ & 1.90 & 2.50 & 1.49 & 2.33 & \\
$\mathrm{NaO}$ & 3.52 & 3.02 & 2.56 & 5.51 & \\
$\mathrm{~K}_{2} \mathrm{O}$ & 4.41 & 4.18 & 5.24 & 0.46 & \\
$\mathrm{~F}_{2} \mathrm{O}_{2}$ & 0.38 & 0.78 & 0.50 & & \\
\hline
\end{tabular}

2.7 Ga (Wilson, 1987). Therefore, they are probably contemporaneous with the $\mathrm{CH} 1$ and $\mathrm{CH} 2$ magmatic stages (2.7-2.8 Ga SHRIMP zircon ages; Alibert and Barbosa, 1992; Marinho et al., 1994). Inherited zircon grains from $\mathrm{CH} 6$ charnockites of the Brejões and related domes are similar to those found in the surrounding basement. As indicated by $\mathrm{Sm}-\mathrm{Nd}$ systematic dating, all these rocks are primitively derived from an ancient source or have involved old component ca 3.0-3.2 for $\mathrm{T}_{\mathrm{DM}}$ (1) $\mathrm{Ga}$ or $2.9-3.1 \mathrm{Ga}$ for $\mathrm{T}_{\mathrm{DM}}$ (2), following the Archean mantle reservoir considered (Table 2).

The dome structures, synchronous with $\mathrm{CH} 6$ charnockite emplacement, are younger, for they contain enclaves of all the surrounding rocks. The domical structures are linked to the metamorphic evolution of the whole area. Indeed, surrounding rocks $(\mathrm{CH} 1$, $\mathrm{CH} 2$ ) but also charnockites (CH6) and their enclaves, all equilibrated in the same pressure and temperature conditions, thus displaying identical $\mathrm{Fe}-\mathrm{Mg}$ partition coefficients in thermodynamic diagrams (Barbosa and Foothills, 1991). Metamorphic timing is constrained by the monazite cooling ages $\left(>750^{\circ} \mathrm{C}\right)$ comprised between $2052 \pm 2$ in a syn tectonic garnet-cordierite partial charnockitic melt and $2044 \pm 1$ Ma from heterogeneous granulites of the adjacent basement. Monazite in $\mathrm{CH} 6$ of the southern Cravolandia dome provided a slightly younger age of $2026 \pm 1 \mathrm{Ma}$. Temperatures conditions determined from the hercynite-quartz association in kinzigitic gneisses located in the surrounding supracrustal units are near $1100{ }^{\circ} \mathrm{C}$ (Barbosa et al., in preparation). These temperatures are significantly higher than those obtained for the regional granulitic condition in the Jequié block $\left(850-870{ }^{\circ} \mathrm{C}, 5-7 \mathrm{kbar}\right)$. There the granulite facies has been dated at $2086 \pm$ $18 \mathrm{Ma}$ (Ledru et al., 1994) and $2061 \pm 6 \mathrm{Ma}$ (Silva et al., 2002). Consequently, charnockitic domes can be assumed to have formed between $2061 \pm 6 \mathrm{Ma}$ and $2044 \pm 1 \mathrm{Ma}$ at Brejões dome and probably later (2026 $\pm 1 \mathrm{Ma}$ ) in the southern Cravolândia dome.

Petrology and geochemistry permitted identification of different types of magmas. The granulitic rocks $\mathrm{CH} 1$ at Laje and $\mathrm{CH} 2$ at Mutuipe are mainly granodioritic to granitic medium-K calc-alkaline suites. CH6 charnockites of Brejões and Santa Inês domes are more siliceous and have a typically granitic composition. Mathematical modelling shows that $\mathrm{CH} 1$ and $\mathrm{CH} 2$ magmas can result from 20 to $30 \%$ fractional crystallisation of a hornblende-bearing and orthopyroxene-free cumulate, thus indicating that $\mathrm{CH} 1$ and $\mathrm{CH} 2$ magmatic precursors (at ca $2.7-2.8 \mathrm{Ga}$ ) were emplaced in amphibolite facies metamorphic conditions. Subsequently they were re-equilibrated under granulite facies conditions, during Paleoproterozoic times. Furthermore, the modelling precludes $\mathrm{CH} 1$ and $\mathrm{CH} 2$ magma derivation by partial melting of older TTG. Indeed, TTG are $\mathrm{SiO}_{2}$-richer than $\mathrm{CH} 1$ and $\mathrm{CH} 2$ parental magmas. On the other hand, geochemical modelling is in agreement with a genesis through partial melting of Archean enriched tholeiite, the LILE-enriched character of the tholeiite accounting for the medium-K character of $\mathrm{CH} 1$ and $\mathrm{CH} 2$, as well as for their negative $\varepsilon_{\mathrm{Nd}}(-1$ to -4 at $2.7 \mathrm{Ga}$; Table 2$)$. The syndome CH6 charnockites result from partial melting processes and are probably derived from a $\mathrm{CH} 2$-type precursor.

During the last decade, several scientific discussions focused on the existence of either two granulitic metamorphisms $(2.7 \mathrm{Ga}$ and $2.0 \mathrm{Ga}$ ) or of only one at $2.0 \mathrm{Ga}$. This work clearly corroborates the existence of the 2.0 event during the Palaeoproterozoic collision between 
the Jequié and Itabuna blocks (Barbosa and Sabaté, 2002). It also shows that, during this event, high temperatures were reached such that Archaean basement could melt under granulitic conditions, thus giving rise to the Brejões dome $\mathrm{CH} 6$ charnockite. On the other hand, the present work is not able to show any evidence of late Archean granulitic metamorphism. Both $\mathrm{CH} 1$ and $\mathrm{CH} 2$ were generated during the late Archean under amphibolite facies conditions. Their granulitic paragenesis was acquired only subsequently during the Paleoproterozoic collision.

\section{Acknowledgements}

This research was funded by $\mathrm{CNPq}$, CAPESCOFECUB collaborative project (no. 381/02) and by CBPM-Companhia Baiana de Pesquisa Mineral. Paulo Henrique Costa and Olivar Lima de Oliveira are acknowledged for the revision of the English manuscript.

\section{References}

Alkmim, F.F., Brito Neves, B.B., Alves, J.A.C., 1993. Arcabouço tectônico do Cráton do São Francisco: uma revisão. In: Misi, A., Dominguez, J.M.L. (Eds.), O Cráton do São Francisco, Salvador. Soc. Bras. Geol., pp. 45-62.

Aillon, M.P., 1992. Caracterização petroquimica e do metamorfismo das rochas granulíticas da região de Cachoeira-São FelixCruz das Almas, Bahia. M.Sc. thesis, unpublished, University of Bahia, Brazil, 165 p.

Alibert, C., Barbosa, J.S.F., 1992. Ages U-Pb déterminés à la "SHRIMP" sur des zircons du Complexe de Jequié, Craton du São Francisco, Bahia, Brésil. In: 14 Réunion Science de la Terre, Toulouse. Soc. Géol. France, p. 4.

Almeida, F.F.M. de, 1977. O Craton do São Francisco. Rev. Bras. Geoc. 7, 349-364.

Arcanjo, J.B.A., Barbosa, J.S.F., de Oliveira, J.E., 1992. Caracterização petrográfica e metamórfica dos granulitos do Arqueano/Proterozóico inferior da Região de Itabuna—Bahia. Rev. Bras. Geoc. 22 (1), 47-55.

Barbosa, J.S.F., 1988. Principais geobarômetros utilizados em granulitos. Análise dos resultados de um exemplo do sul da Bahia-Brasil. Rev. Bras. Geoc. 18 (2), 162-169.

Barbosa, J.S.F., 1990. The granulites of the Jequié Complex and Atlantic Mobile Belt, Southern Bahia, Brazil—an expression of Archaean-Proterozoic plate convergence. In: Vielzeuf, D., Vidal, Ph., (Eds.), Granulites and Crustal Evolution. Proceedings of ARW, Clermont Ferrand (France), Springer-Verlag, pp. 195221.
Barbosa, J.S.F., Dominguez, J.M.L., 1996. Texto Explicativo para o Mapa Geológico da Bahia ao Milionésimo. SICM/ SGM, Salvador, (Edição Espécial), 400 p.

Barbosa, J.S.F., Fonteilles, M., 1989. Caracterização dos protólitos da região granulítica do sul da Bahia. Rev. Bras. Geoc. 19 (1), $3-16$.

Barbosa, J.S.F., Fonteilles, M., 1991. Síntese sobre o metamorfismo da região granulítica do sul da Bahia. Brasil. Rev. Bras. Geoc. 21 (4), 328-341.

Barbosa, J.S.F., Silva, F.C.A., Sapucaia, N.S., Iyer, S.S., 1998. Petrological and geochemical characteristics of the granulitic terrain of Brejões, Bahia, Brazil. Gondwana Res. (3/4), 343-356.

Barbosa, J.S.F., Sabaté, P., 2002. Geological features and the Paleoproterozoic collision of four Archaean crustal segments of the São Francisco Craton, Bahia, Brazil. A synthesis. Anais da Academia Brasileira de Ciências 74 (2), 343-359.

Barker, F., 1987. Trondhjemites: definition, environment and hypothesis of origin. In: Barker, F. (Ed.), Trondhjemites, Dacites and Related Rocks. Elsevier, Amsterdam, pp. 1-12.

Barker, F., Arth, J.G., 1976. Generation of trondhjemitic-tonalitic liquids and Archaean bimodal trondhjemite-basalt suites. Geology 4, 596-600.

Bouhallier, H., Chardon, D., Choukroune, P., 1995. Strain patterns in Archaean dome and basin structures: the Dharwar craton (Karnataka, south India). Earth Planet. Sci. Lett. 135, 57-75.

Chardon, D., Choukroune, P., Jayananda, M., 1998. Sinking of the Dharwar basin: implications for Archaean tectonics. Precambrian Res. 91, 15-39.

Choukroune, P., Bouhallier, H., Arndt, N.T., 1995. Soft lithosphere during periods of Archaean crustal growth or crustal reworking. In: Coward, M., Ries, A.C. (Eds.), Early Precambrian Processes. Geol. Soc. Lond., Spec. Publ. 95, 67-86.

Choukroune, P., Ludden, J.N., Chardon, D., Calvert, A.J., Bouhallier, H., 1997. Archaean crustal growth and tectonic processes: a comparison of the Superior Province, Canada and the Dharwar Craton, India. In: Burg, J.P., Ford, M. (Eds.), Orogeny Through Time. Geol. Soc. Lond., Spec. Publ. 121, 63-98.

Cocherie, A., Legendre, O., Peucat, J.J., Kouamelan, A.N., 1998. Geochronology of polygenetic monazites constrained by in situ electron microprobe Th-U-total $\mathrm{Pb}$ determination: implications for $\mathrm{Pb}$ behavior in monazite. Geochim. Cosmochim. Acta 62 (14), 2475-2497.

Condie, K.C., 1981. Geochemical and isotopic constraints on the origin and source of Archaean granites. Geol. Soc. Aust. Spec. Publ. 7, 469-479.

Cordani, U.G., 1973. Evolução Geológica Precambriana da Faixa Costeira do Brasil entre Salvador e Vitória. Tese de L. Doc. Universidade de São Paulo, Brazil, 80 p.

Cordani, U.G., Iyer, S.S., 1978. Geochronological Investigation on the Precambrian Granulite terrain of Bahia, Brazil. Precambrian Res. 9, 255-276.

Cordani, U.G., Sato, K., Marinho, M.M., 1985. The geologic evolution of the ancient granite-greenstone terrane of central-southern Bahia, Brazil. Precambrian Res. 27, 187-213.

Figueiredo, M.C.H., 1989. Geochemical evolution of Eastern Bahia, Brazil: a probably early-proterozoic subduction-related magmatic arc. J. South Am. Earth Sci. 2 (2), 131-145. 
Figueiredo, M.C.H., Barbosa, J.S.F., 1993. Terrenos Metamórficos de Alto Grau do Cráton do São Francisco. In: Dominguez, J.M.L., Misi, A. (Eds.), O Cráton do São Francisco Salvador, SBG/SGM/CNPq. Publicação Especial 63-83.

Fornari, A., Barbosa, J.S.F., 1994. Litogeoquimica do batólito enderbítico-charnockítico do Complexo Jequié na região de Laje e Mutuipe, Bahia. Rev. Bras. Geoc. 24 (1), 13-21.

Gorman, B.E., Pearce, T.H., Birkett, T.C., 1978. On the structure of Archean greenstone belts. Precambrian Res. 6, 23-41.

Irvine, T.N., Baragar, W.R.A., 1971. A guide to the chemical classification of the volcanic rocks. Can. J. Earth Sci. 8, 523-548.

Iyer, S.S., Barbosa, J.S.F., Choudhuri, A., Krouse, H.S., 1995. Possible sources de $\mathrm{CO}_{2}$ in granulite facies rocks: carbon isotope evidence from the Jequié Complex Brazil. Petrology 3, 226-237.

Lameyre, J., Bowden, P., 1982. Plutonic rock type series: discrimination of various granitoid series and related rocks. J. Volcanol. Geotherm. Res. 14, 169-186.

Leal, R.B.L., Cunha, J.C., Cordani, U.G., Teixeira, W., Nutman, A.P., Leal, A.B.M., Macambira, J.B.M., 2003. SHRIMP U$\mathrm{Pb}{ }^{207} \mathrm{~Pb} /{ }^{206} \mathrm{~Pb}$ zircon dating and $\mathrm{Nd}$ isotopic signature of the Umburanas greenstone belt, Northern São Francisco Cráton, Brazil: evidence for intraplate extensional tectonics between 3340-3150 Ma. J. South Am. Earth Sci. 15, 775-785.

Ledru, P., Cocherie, A., Barbosa, J.S.F., Johan, V., Onsted, T., 1994. Age du métamorphisme granulitique dans le Craton du São Francisco (Brésil). Implications sur la nature de l'orogène transmazonien. C.R. Acad. Sci. Paris 211, 120-125.

Marinho, M.M., Vidal, Ph., Alibert, C., Barbosa, J.S.F., Sabaté, P., 1994. Geochronology of the Jequié-Itabuna granulitic belt and of the Contendas-Mirante volcano-sedimentary belt. Boletim de Instituto de Geociências, Universidade de São Paulo, Brazil, Publicação Especial 17, 73-96.

Martin, H., 1987. Petrogenesis of Archaean trondhjemites, tonalites and granodiorites from eastern Finland: major and trace elements geochemistry. J. Petrol. 28, 921-953.

Martin, H., 1994. The Archaean grey gneisses and the genesis of the continental crust. In: Condie, K.C. (Ed.), The Archaean Crustal Evolution. Elsevier, Amsterdam, pp. 205-259.

Martin, H., Auvray, B., Blais, S., Capdevila, R., Hameurt, J., Jahn, B.-M., Piquet, D., Querré, G., Vidal, Ph., 1985. Origin and geodynamic evolution of the Archaean crust of eastern Finland. Bull. Geol. Soc. Finland 56, 135-160.

Martin, H., Peucat, J.J., Sabaté, P., Cunha, J.C., 1991. Crustal evolution in the early Archaean of South America: example of the Sete Voltas Massif, Bahia State, Brazil. Precambrian Res. 82, 35-62.

Martin, H., Sabaté, P., Peucat, J.J., Cunha, J.C., 1997. Un segment de croûte continentale d'âge Archéen ancien (3.4 milliards d'années): le massif de Sete Voltas (Bahia-Brésil). C.R. Acad. Sci. Paris 313, 531-538.

Mascarenhas, J.F., Garcia, T.M.W., 1986. Mapa geocronológico do Estado da Bahia. Secretaria de Minas e Energia. Texto Explicativo, Salvador, Bahia, Brasil, 130 p.

Miranda, L.L.F., Moraes, A.M.V., Cruz, M.J.M., Silva, E.C.J., 1983. Projeto Jequié-Boa Nova. Salvador, CBPM, 5 v. Convênio SME/CBPM (unpublished).

Nutman, A.P., Cordani, U.G., 1993. SHRIMP U-Pb zircon geochronology of Archaean granitoids from the Contendas-
Mirante area of the São Francisco craton, Bahia, Brasil. Precambrian Res. 63, 179-188.

O'Connor, J.T., 1965. A classification for quartz-rich igneous rocks based on feldspar ratios. U.S. Geol. Surv. Prof. Pap. 525/B, 79-84.

Oliveira, J.E., Barbosa, J.S.F., Arcanjo, J.B.A., 1993. Petrografia e Petroquímica dos Granulitos da Região de Itabuna, Bahia. Rev. Bras. Geoc. 23 (4), 356-369.

Peucat, J.J., Kouamelan, A., 1997. TIMS evaporation Pb dating applied to monazite and baddeleyite. In: Proceedings of the EUG IX, Conference of the European Union of Geosciences, Strasbourg, Terra Nova, pp. 23-27.

Peucat, J.J., Ménot, R.P., Monnier, O., Fanning, C.M., 1999. The Terre Adélie basement in the East-Antarctica Shield: geological and isotopic evidence for a major $1.7 \mathrm{Ga}$ thermal event; comparison with the Gawler Craton in South Australia. Precambrian Res. 94, 205-224.

Peucat, J.J., Mascarenhas, J.F., Barbosa, J.S.F., Souza, S.L., Marinho, M.M., Fanning, C.M., Leite, C.M.M., 2002. 3.3 Ga SHRIMP U$\mathrm{Pb}$ zircon age of a felsic metavolcanic rock from the Mundo Novo Greenstone belt in the São Francisco Craton, Bahia (NE Brazil). J. South Am. Earth Sci. 15, 363-373.

Pupin, J.P., 1980. Zircon and granite petrology. Contrib. Mineral. Petrol. 73, 207-220.

Rayleigh, J., 1896. Theoretical considerations respecting the separation of gases by diffusion and similar processes. Philos. Mag. 42, 77-107.

Santos Pinto, M., Peucat, J.J., Martin, H., Sabaté, P., 1998. Recycling of the Archaean crust: the case study of the Gavião, State of Bahia, NE Brazil. J. South Am. Earth Sci. 11-5, 487-498.

Schobbenhaus, C., Campos, D.A., Derze, G.R., Asmus, H.E., 1984. Geologia do Brasil. Texto Explicativo do Mapa Geológico do Brasil e da área oceânica adjacente, incluindo depósitos minerais. Depto. Nac. Prod. Min. 501 p.

Shaw, D.M., 1970. Trace element fractionation during anatexis. Geochim. Cosmochim. Acta 34, 237-243.

Silva, L.C., Armstrong, R., Delgado, I.M., Pimentel, M., Arcanjo, J.B., Melo, R.C., Teixeira, L.R., Jost, H., Carcoso Filho, J.M., Pereira, L.H.M., 2002. Reavaliação da evolução geológica em terrenos Précambrianos brasileiros com base em novos dados U$\mathrm{Pb}$ SHRIMP. Parte I: Limite centro-oriental do Cráton do São Francisco. Rev. Bras. Geoc. 33 (4), 501-502.

Stacey, J.S., Kramer, J.D., 1975. Approximation of terrestrial lead isotopic evolution by a two stage model. Earth Planet. Sci. Lett. 26, 207-221.

Steiger, R.H., Jäger, E., 1977. Subcommision on Geochronology: convention to use of decay constants in geo and cosmochronology. Earth Planet. Sci. Lett. 36, 359-362.

Streckeisen, A., 1975. To each plutonic rock its proper name. Earth Sci. Rev. 12, 1-33.

Störmer, J.C., Nicholls, J., 1978. XLFRAC: a program for interactive testing of magmatic differentiation models. Comput. Geosci. 87, 51-64.

Sun, S.S., 1982. Chemical composition and origin of the Earth primitive mantle. Geochim. Cosmochim. Acta. 46, 179-192.

Teixeira, W., Sabaté, P., Barbosa, J.S.F., Noce, C.M., Carneiro, M.A., 2000. Archean and Paleoproterozoic tectonic evolution of the São 
Francisco Cráton. In: Cordani, U.G., Milani, E.J., Thomaz Filho, A., Campos, D.A. (Eds.), Tectonic Evolution of South America. Proceedings of the 31 st International Geological Congress, Rio de Janeiro, $856 \mathrm{p}$.

Xavier, R.P., Barbosa, J.S.F., Iyer, S.S., Choudhuri, A., Valarelli, J.V., Cordani, U.G., 1989. Low density carbonic fluids in the Archaean granulite facies terrains of the Jequié Complex, Bahia, Brazil. J. Geol. 97, 351-359.
Wilson, N., 1987. Combined Sm-Nd, $\mathrm{Pb}-\mathrm{Pb}$ and $\mathrm{Rb}-\mathrm{Sr}$ geochronology and isotope geochemistry in polymetamorphic precambrian terrains: examples from Brazil and Channel Island, U.K. M.Sc. thesis, unpublished, Oxford University, U.K., 250 p.

Winge, M., 1984. A Seqüência vulcanossedimentar do Grupo Rio Capim, Bahia. In: Viveiros Sá, P.V., Duarte, F.B. (Eds.), Geologia e Recursos Minerais do Estado da Bahia, Textos Básicos, Salvador, SME/CPM, 5, pp. 43-103. 